\title{
Finite Element Method Analysis Applied to the Study of a Corner Joint in Reinforced Concrete Structures
}

\author{
Guillaume Hervé Poh'sie, Davy Marcel Bile Bile Abessolo, Giuseppe Cardillo, Carmelo Majorana
}

\begin{abstract}
The principal objective for this work was to extend the field of application of FEM to space frame beam-column connections under static loading and with lateral displacements. A four-storey building was modelled under static load condition. Horizontal and vertical structural elements were designed according to Eurocode 2. In order to understand the behavior of the external node made by under column, two beam and upper column, two models using correct boundary condition and nonlinear behavior of materials have been done using Abaqus Software The analysis was performed on an interior and an exterior joint models each in two conditions: unconfined and confined joint varying the distributions of number of stirrups for the beam reinforcement and the column reinforcement.A sup structural model to submit to numerical analysis have been performed, the Concrete Damage Plasticity model (CDPM) has been chosen for fit the nonlinear behavior for the concrete and the elastoplastic model has been adopted for the nonlinear behavior for the reinforcement (stirrups, longitudinal and vertical bars). The models were then verified against already existing and validated analytical results and results of experiments conducted on specimens
\end{abstract}

Keywords: Finite Element Method, joints, Reinforced concrete structures, Ductility

\section{INTRODUCTION}

The continuous failure and collapse of buildings and other infrastructures under gravity loads or laterally induced seismic loads or wind loads is a crucial phenomenon in the construction sector. This failure can be due to several reasons among which the inadequate consideration design in the joint project. Among the existing joint types, the external (corner) joint is the subject under study. It has been proven that concrete is a brittle material and brittleness of a structural member has unfavorable effects on the overall mechanical response of a structure.

Manuscript received on July 11, 2021.

Revised Manuscript received on July 29, 2021.

Manuscript published on August 30, 2021.

* Correspondence Author

Dr. Eng. Guillaume Hervé POH'SIE*, Assistant Lecturer, Department of Mechanical Engineering, Structural Civil Engineer, College of Technology, University of Buea, Cameroon. Email : pguillaumeherve.ing@gmail.com

Eng. Davy Marcel Bile Bile Abessolo, Structural Civil Engineer, National Advanced School of Public Works of Yaounde, Cameroon.

Eng. Giuseppe Cardillo, Assistant Professor of Structural Mechanics, University of Padua, Italy.

Prof. Carmelo Majorana, Professor, Structural Mechanics and Engineering, University of Padua, Italy.

(c) The Authors. Published by Blue Eyes Intelligence Engineering and Sciences Publication (BEIESP). This is an open access article under the CC BY-NC-ND license (http://creativecommons.org/licenses/by-nc-nd/4.0/)
During a seismic event, shear failure can occur prematurely stopping the beams from attaining ultimate flexural capacity leading to total collapse of the building as a result of exposure to severe damages at the joint region. Numerous studies have been carried with the aim of investigating the behavior of RC joints using various investigation techniques one of the recent being FEM analysis. Emphasis was laid on the shear response mechanism of the joint. The models presented in this work and analysis are corner beam-column connection focusing on the shear failure mode under pure static loading first, then static loading with lateral displacement.

\subsection{Joint shear mechanisms}

Internal mechanism of failure according to Paulay and Priestley, 1992 from adjacent beam and column to the joint (Figure I.1), create joint shear forces in both directions (horizontal and vertical). These joint forces result in crack formation (diagonally) of the concrete core. The diagonal compressive forces generated at the corners of the joint are responsible for resisting the most of the total shear force and constitute the strut part of the strut and tie mechanism (Figure I.2). Also, steel forces are transferred through bonds with concrete, thereby producing a compression zone (Figure I.2 (b)) in the joint core with diagonal cracks and a total diagonal compression force, $\mathrm{D}_{\mathrm{c}}$. The mechanism associated here is the truss mechanism. Transverse shear reinforcements are provided in this case, for effective resistance, to resist directly when the concrete core becomes severely cracked due to diagonal tensile strains (assuming no bond deterioration). 


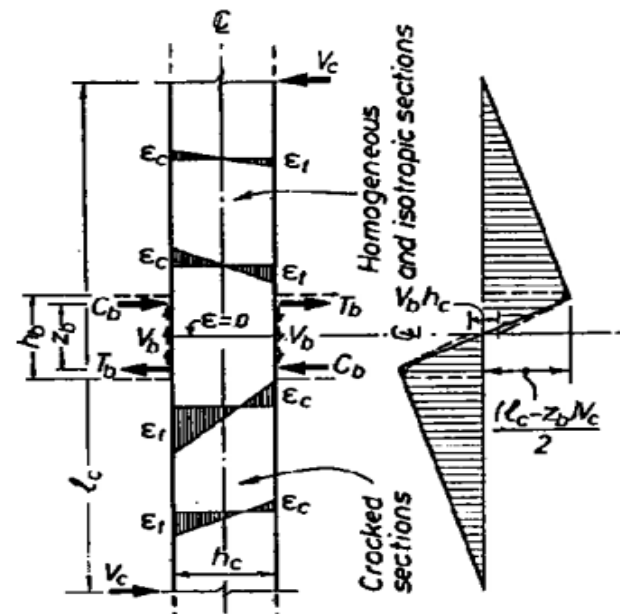

(a) Forces acting
On column (b) Bending moment

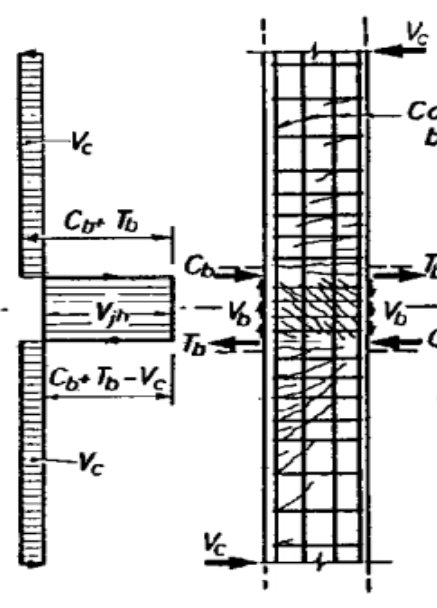

(c) Shear forces (d) Crack patterns

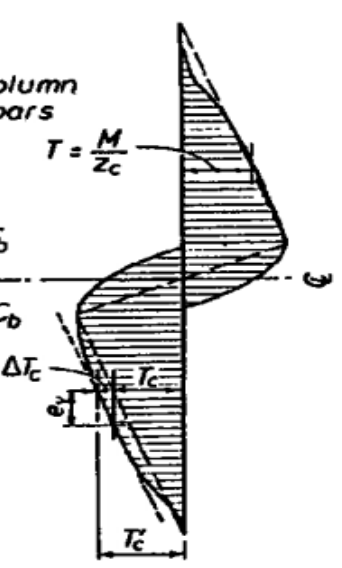

(e) Variation of internal tension forces along the column

Figure I.1. sample distribution forces behavior (Paulay and Priestley, 1992)
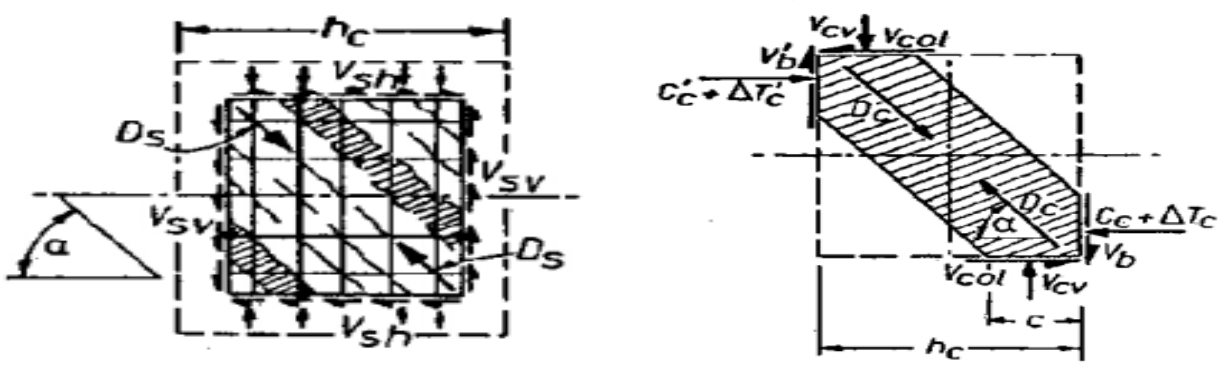

(b) Diagonal compression field under seismic loading

(a) Steel resisting mechanism

anism internal joint (Paulay and Priestley, 1992)

\subsection{Shear mechanisms in exterior joints}

Accordingly, an exterior beam-column joint is a joint in which we have two columns (under and upper) two beams in the plane, one in which two beams frame orthogonally in the same column on two adjacent faces (space frame) as shown in Figure I.3. In an exterior joint, the resisting mechanisms are the same as those in an interior joint. The strut and truss mechanisms are common to all types of joints irrespective of their location in the building. The main difference is at the number of elements framing into the joint. An example is an intermediate interior beam-column joint which six elements framing into it of which we have four beams and two columns. Whereas, an edge joint, still in a plane frame, has four elements consisting of three beams and two columns.

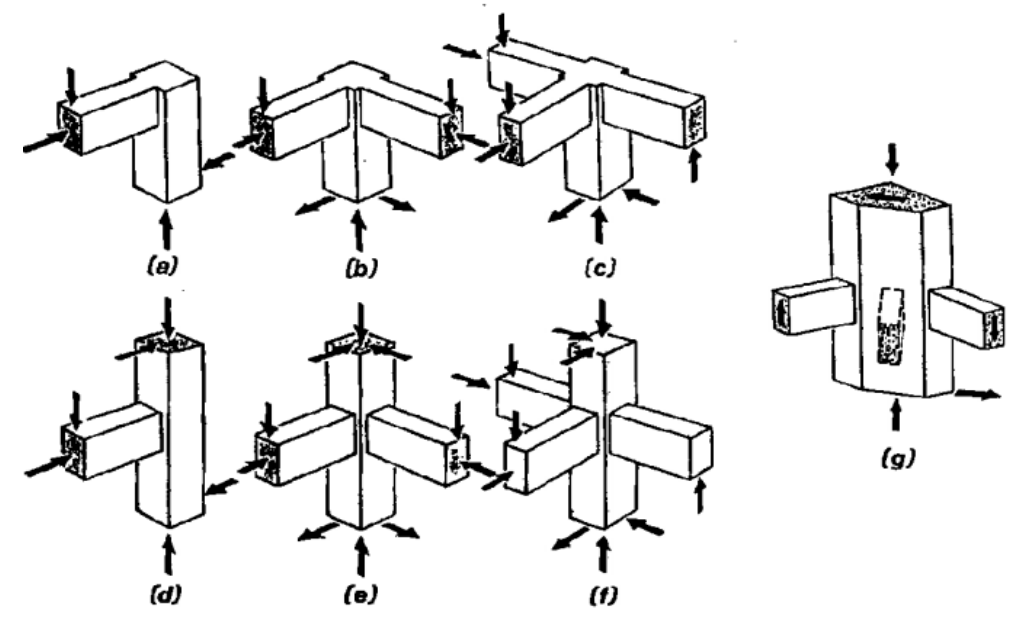

Figure I.3. Exterior connections (Paulay. T and Priestley M.N.J, 1992)

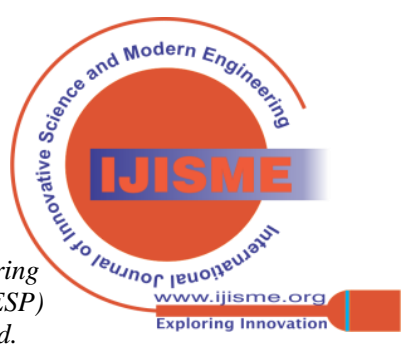




\subsection{Actions acting at an exterior joint whit different configurations}

Because only one beam fames in a column in an exterior joint in a plane frame, the joint shear strength will generally be lesser compared to internal joints. The assumptions made for the beam-column interior joints are valid for the exterior joint as well. $\mathrm{T}, \mathrm{C}_{\mathrm{c}}$, and $\mathrm{C}_{\mathrm{s}}$ denote Tensile stress resultants, compression stress resultant in concrete and compression stress resultant in steel respectively.

\subsubsection{Development of shear forces}

Shear forces in the horizontal and vertical directions are given by the expressions below.

$$
\begin{aligned}
V_{j h} & =T-V_{c o l} \\
V_{j v} & =\left(\frac{h_{b}}{h_{c}}\right) V_{j h}
\end{aligned}
$$

Where $T=f_{s} A_{s}$ or $\lambda_{0} f_{y} A_{s}$ depending on; if an elastic beam section is considered or if in a column face, for a beam plastic hinge, the critical section is considered.

Similarly, to interior joints, concrete contribution to shear strength as well as shear reinforcement contribution can be computed separately. The concrete and steel contributions are estimated with the following expressions.

$$
\begin{gathered}
V_{c h}=C_{c}+\Delta T_{c}-V_{c o l} \\
V_{s h}=V_{j h}-V_{c h} \\
V_{c v}=V_{c h} \tan \alpha \\
V_{s v}=D_{s} \sin \alpha
\end{gathered}
$$

\subsubsection{Determination of joint shear force}

To estimate the shear force, $\mathrm{V}_{\mathrm{jh}}$, the moment capacities in the design of Ductility Class High Moment Resisting Frame (DCHMRF) is accounted for, taking into account the over-strength factor $\left(\gamma_{\mathrm{Rd}}=1.2\right.$ for DCHMRF; EC8 5.5.2.3(2)) coming as a result of steel strain hardening, with a reinforcing steel over-strength factor due to steel strain hardening. The expressions below are that used to evaluate the design shear forces in exterior joints (Eq. 1.7).

(Eq. 1.7)

$$
V_{j h d}=\gamma_{R d} A_{s 1} f_{y d}-V_{c}
$$

Where As1 is upper beam reinforcements and As2 lower beam reinforcements.

$\mathrm{Vc}$ is shear force in column computed from beam moment capacities, considering that the point of contra flexure is at half the height of the column as shown in Figure I.4.

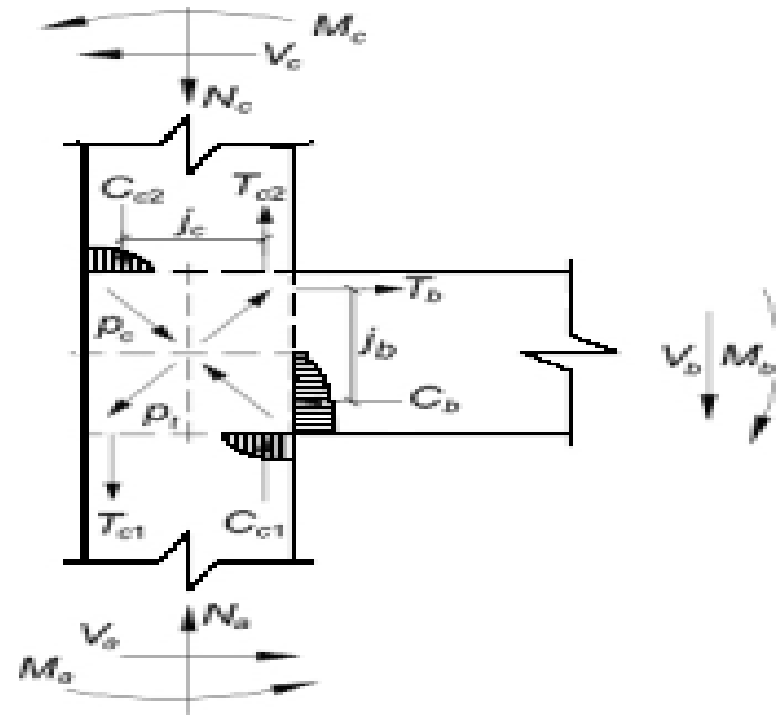

Figure I.4. Evaluation of column shear force (Prof. Dr.-Eng. Rolf Eligehausen, Prof. Dr.-Eng. Habil Manfred Bischoff and Prof. Dr.-Eng. Jan Hofmann, 2013)

\subsubsection{Joint effective area}

As recommended by Eurocode 8, the joint effective area that resist the joint shear forces is determined as follows:

- If the column width $b_{c}>$ the beam width $b_{w}$, then the effective joint width is given as

$b_{j}=\min \left\{b_{c},\left(b_{w}+0.5 h_{c}\right)\right\} ;($ EC8 Eqn.5.34a, 5.5.3.3(2))

- If the column width $b_{c}<$ the beam width $b_{w}$, then the effective joint width is given as

$b_{j}=\min \left\{b_{w},\left(b_{c}+0.5 h_{c}\right)\right\} ;($ EC8 Eqn.5.34a, 5.5.3.3(2))

\subsubsection{Verification of joint shear resultant force}

The estimation of the shear resultant force is done by comparison with the design shear strengths shown below (EC 8, 5.5.3.3(2)):
$\mathrm{V}_{\mathrm{jhd}} \leq$
$0.8 \eta f_{c d} \sqrt{1-\frac{v_{d}}{\eta}} b_{j} h_{j} \quad$ for exterior joints

(EC8 Eq 5.33)

(Eq. 1.8)

Where, $\eta=0.6\left(1-f_{c k} / 250\right)$ is a reduction factor adopted.

$f_{c d}$ is the concrete strength under compression.

$v_{d}$ is the normalized axial force above the connection in the column

If for some reasons the requirements above aren't met, the solution may be to increase the effective area of the joint.

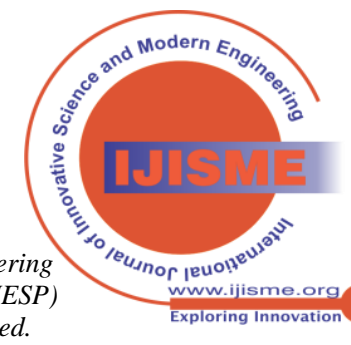


This should be done by changing the beam size or column size or in some cases both. Another solution can be to increase the concrete strength.

\subsubsection{Confined joint reinforcement design}

The Eurocode 8, for limiting the tensile stress in concrete (in the diagonal direction), $\sigma_{\mathrm{c}, \max }$ to $\mathrm{f}_{\mathrm{ctd}}$, recommends adequate horizontal and vertical confinement of the joint in the form of hoops placed horizontally of which the diameter should not be less than $6 \mathrm{~mm}$ with the joint such that:

$$
\begin{aligned}
& \frac{A_{s h \cdot} \cdot f_{y w d}}{b_{j} \cdot h_{j}} \geq \frac{\left(\frac{v_{j h d}}{b_{j} \cdot h_{j c}}\right)^{2}}{f_{c t d}+v_{d} \cdot f_{c d}}-f_{c t d} \\
& \Leftrightarrow A_{s h} \geq\left[\frac{\left(\frac{v_{j h d}}{b_{j} \cdot h_{j c}}\right)^{2}}{f_{c t d}+v_{d} \cdot f_{c d}}-f_{c t d}\right] \frac{b_{j} h_{j w}}{f_{y w d}}
\end{aligned}
$$

An alternative to the above rule, to assure safety of the connection after cracking, is provided by the code.

$$
A_{s h} f_{y w d} \geq \gamma_{R d} A_{s 2} f_{y d}\left(1-0.8 v_{d}\right)
$$

For exterior joints

$$
\text { (Eq. 1.10) }
$$

\section{FE MODEL OF THE CORNER JOINT}

\subsection{General procedure}

The evaluation procedure goes thus;

- The choice of the type of structure, load patterns and analyses;
- Gravity load design and detailing of the building and selection of the joints to be evaluated;

- Evaluation of joint moment capacity and shear capacity based on beam yielding assumption;

- 3D-finite element modelling, non-linear push-over analyses of the selected joint;

\subsubsection{Description of the case study}

A three - storey reinforced concrete structure intended for office use is modelled and designed. All the details on design of the structure re found in the annexes. It is a rectangular floor, with its length being $23.5 \mathrm{~m}$ and the width $18.9 \mathrm{~m}$. The slab is assumed to be a reinforced concrete slab with hollow blocks of thickness $20 \mathrm{~cm}$. The height of the building from foundation base is $12.5 \mathrm{~m}$ with the height of the ground floor being equal to $3.5 \mathrm{~m}$ and that of the other floors equal to $3 \mathrm{~m}$ for each of the three levels. Regularity of the building is verified in plan and in elevation without setback, and is designed as a DCH for increased resistance to laterally-induced seismic actions and to undergo larger deformations before failure. By its use, the four storey building is classified as a category B building. To this building corresponds to loading conditions described in Tableau II.1 and

Tableau II.2. Design was done according to Eurocodes $0,1,2$ and 8 for the horizontal structural element and the vertical structural element. The reinforcement shown below is obtained as a result of the design.

Tableau II.1. Structural load of building

\begin{tabular}{|c|c|c|c|}
\hline Nature & Description & Value & Unit \\
\hline $\mathrm{G}_{1 \mathrm{~K}}$ & Hollow body slab $(16+4 \mathrm{~cm})$ & 2 & $\mathrm{MPa}$ \\
\hline
\end{tabular}

Tableau II.2. Non-structural load of the building

\begin{tabular}{|l|l|c|c|}
\hline Nature & \multicolumn{1}{|c|}{ Description } & Value & Unit \\
\hline $\mathrm{G}_{2 \mathrm{k}}$ & Screed (3cm thickness) & 0.3 & $\mathrm{kN} / \mathrm{m}^{2}$ \\
\hline $\mathrm{G}_{2 \mathrm{k}}$ & $\begin{array}{l}\text { Coated under slab }(1.25 \mathrm{~cm} \\
\text { thickness) }\end{array}$ & 0.2 & $\mathrm{kN} / \mathrm{m}^{2}$ \\
\hline $\mathrm{G}_{2 \mathrm{k}}$ & Partition wall & 1.0 & $\mathrm{kN} / \mathrm{m}^{2}$ \\
\hline \multicolumn{2}{|c|}{ Total $\mathrm{G}_{2 \mathrm{k}}$} & 1.5 & $\mathrm{kN} / \mathrm{m}^{2}$ \\
\hline
\end{tabular}



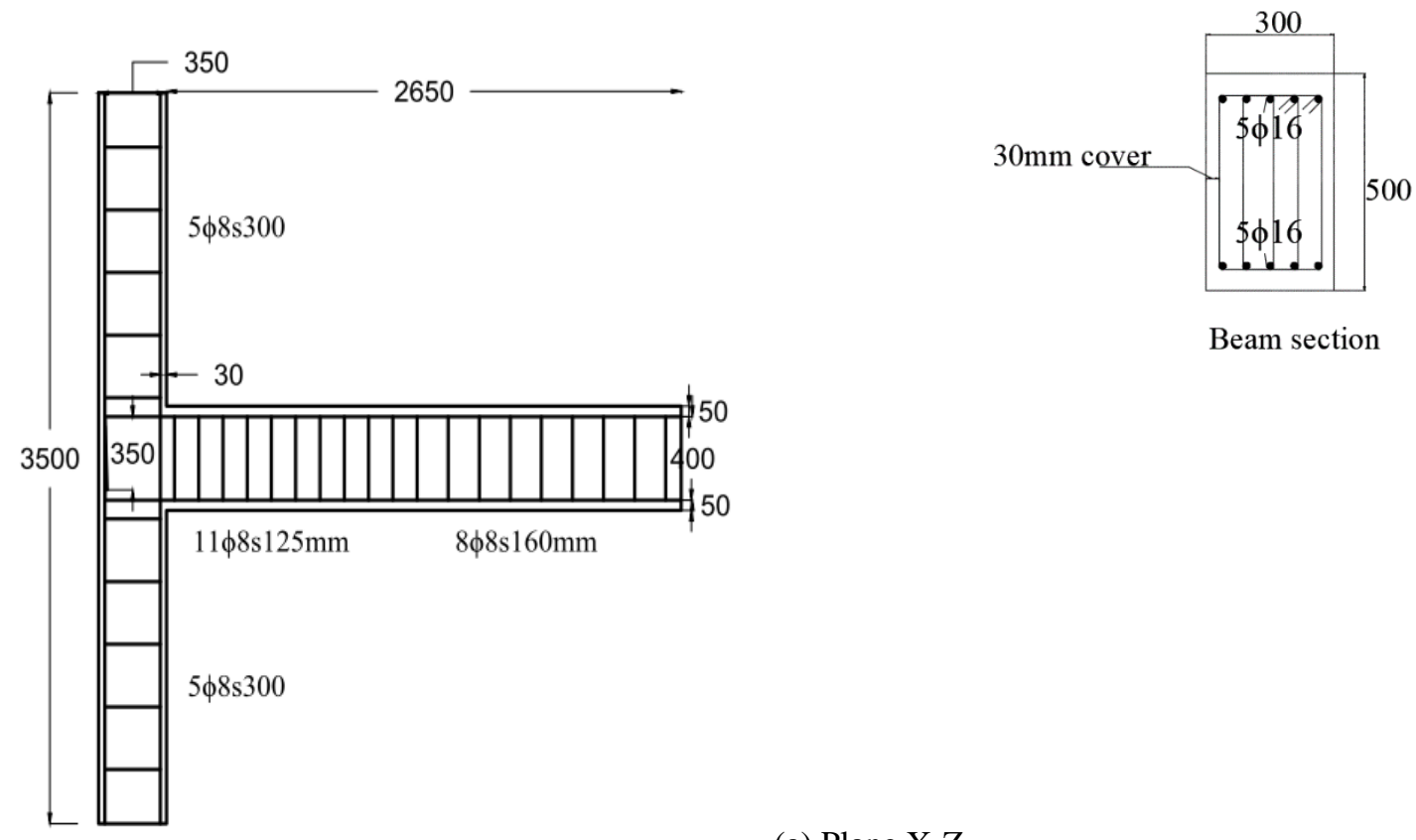

Beam section

(a) Plane X-Z
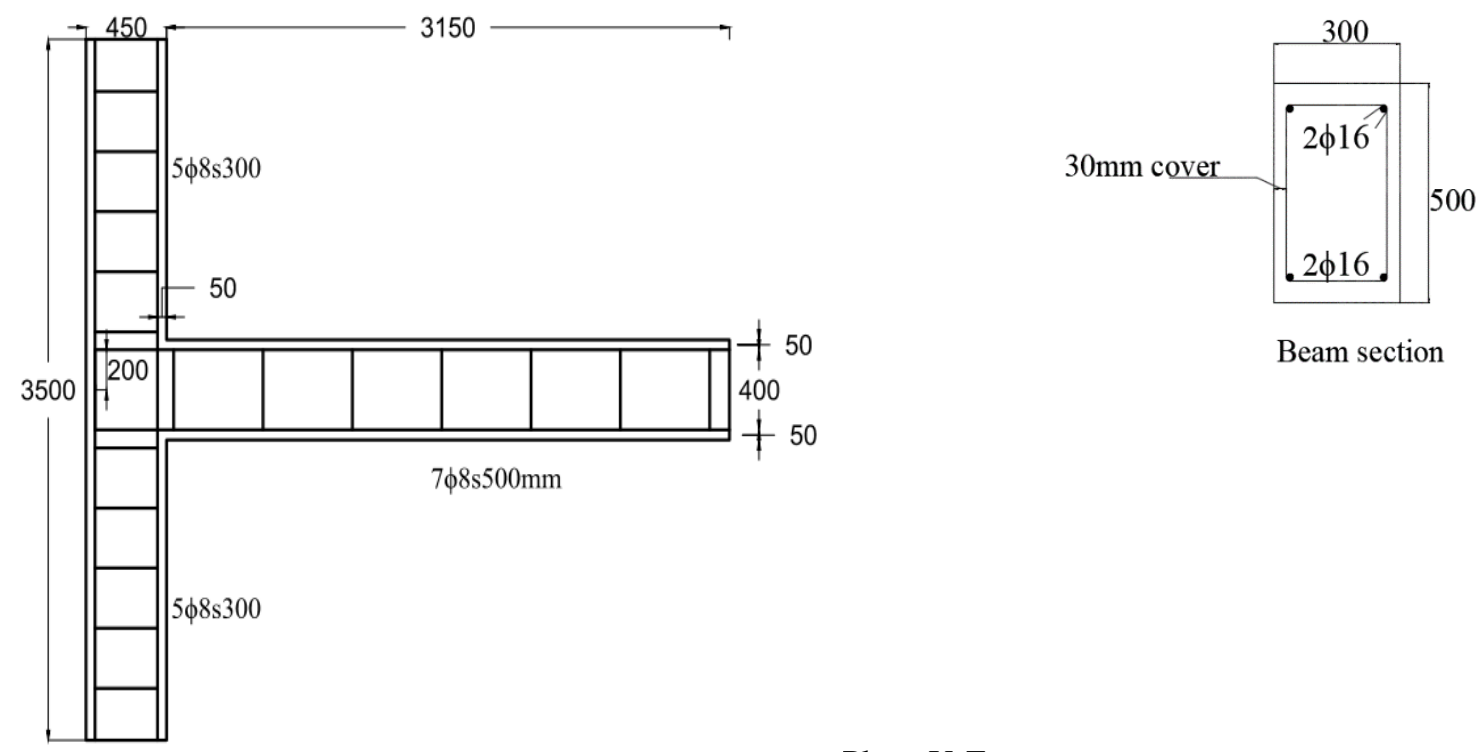

Beam section

Plane Y-Z

Figure II.1. Unconfined corner joint

Minimum reinforcement at joint core for the load arrangement is provided for by EC 8 corresponding to $2 ø 8 \mathrm{~mm}$ spaced by minimum 30mm.

\subsection{FEM analysis of corner joint}

The connection is studied under two loading conditions one of which is the static loading and in the second, a lateral force is applied on the model on the axis parallel to that of the principal beams. Results of the finite element analysis will be compared for confined and unconfined joints, for the two loading conditions. Experimental results performed by known scientists and engineers and existing theories will be used to verify the various finite element models.

\subsubsection{Joint Element}

To avoid interlocking effect due to shear, reduced integration (C3D8R) is used in the modeling of concrete elements. These concrete elements are modelled as 8-noded hexahedral (brick) elements in 3D having 3 degrees of freedom in each node (translations in $\mathrm{X}, \mathrm{Y}$ and $\mathrm{Z}$ directions). For reinforcement modelling, T3D2 truss elements are used having 3 degrees of freedom in each node (translations in $\mathrm{X}, \mathrm{Y}$ and $\mathrm{Z}$ directions of global coordinates system). To properly simulate the bond interaction between the concrete and the reinforcement, the embedded region method is used. It simulates perfect bond between reinforcement and surrounding concrete. The global model is shown in Figure II.2a. For the concrete as well as the reinforcement (steel bars and stirrups), the same mesh size is adopted.

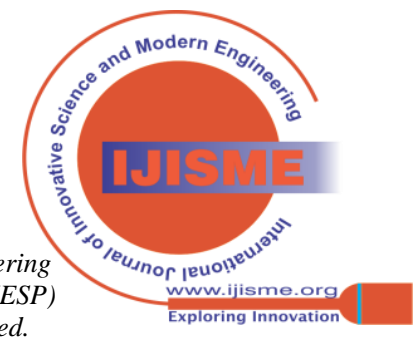




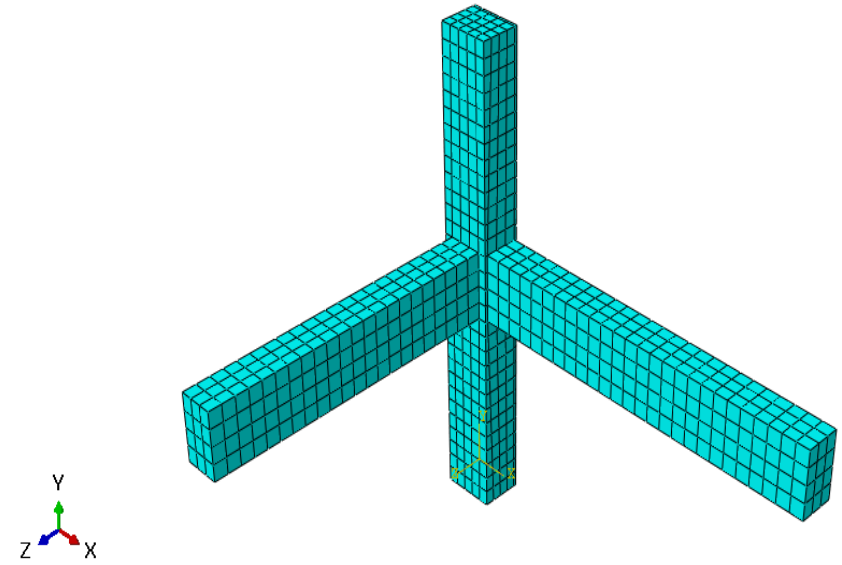

(a) Mesh adopted for the concrete part of corner joint

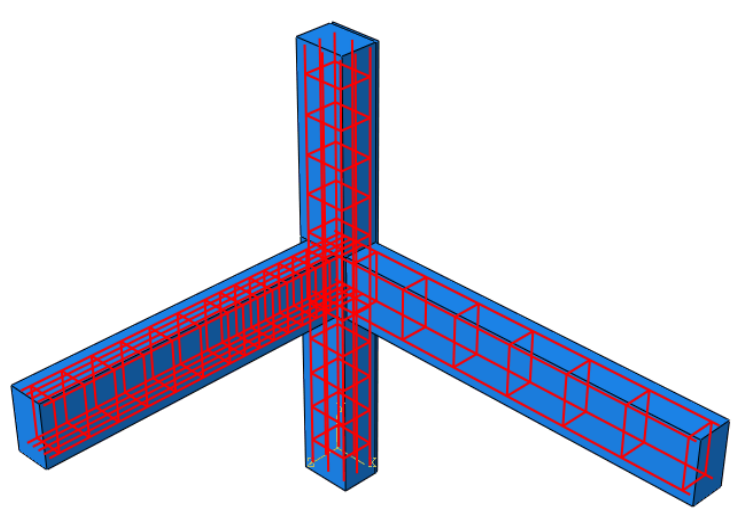

(b) longitudinal bars and stirrups details of corner joint

Figure II.2. Model specimens

The geometric properties used in the above model including the detail reinforcement are both from the design of the horizontal and vertical elements. The various dimensions are shown in Figure II.1.

\subsubsection{Concrete and steel parameters}

Concrete material together with the reinforcements for both bending and shear, are modelled in ABAQUS/Standard as shown in the tables from Table II.1 to

Table II.5. Finite element analysis (nonlinear) is thus conducted on the calibrated corner joint model. The various values of the parameters are shown in the tables below.

Table II.1. Concrete elastic properties

\begin{tabular}{|c|c|c|}
\hline \multirow{2}{*}{$\begin{array}{l}\text { Density } \\
\left(\mathrm{kN} / \mathrm{m}^{3}\right)\end{array}$} & \multicolumn{2}{|c|}{ Elastic properties } \\
\hline & $\begin{array}{l}\text { Young modulus } \\
\left(\mathrm{N} / \mathrm{mm}^{2}\right)\end{array}$ & Poisson's ratio \\
\hline 25 & 33000 & 0.3 \\
\hline
\end{tabular}

Table II.2. Concrete plastic properties

\begin{tabular}{|c|c|c|c|c|}
\hline \multicolumn{5}{|c|}{ Plasticity } \\
\hline Angle of & Eccentricity & $\mathbf{f}_{\mathbf{b} 0} / \mathbf{f}_{\mathbf{c} 0}$ & $\mathbf{K}$ & Viscosity \\
\hline 1.12 & 0.667 & & & \\
\hline
\end{tabular}

Where:

fb0/fc0: Stress ratio

$\mathrm{K}$ : Shape factor
Table II.3. Concrete Damage Plasticity parameters

\begin{tabular}{|c|c|}
\hline \multicolumn{2}{|c|}{ Compressive behavior } \\
\hline Yield stress $\left(\mathrm{N} / \mathrm{mm}^{2}\right)$ & Inelastic strain \\
\hline 10.2 & 0 \\
\hline 25 & 0.0025615 \\
\hline 3.4 & 0.011 \\
\hline
\end{tabular}

Published By:

Blue Eyes Intelligence Engineering and Sciences Publication (BEIESP) (C) Copyright: All rights reserved.

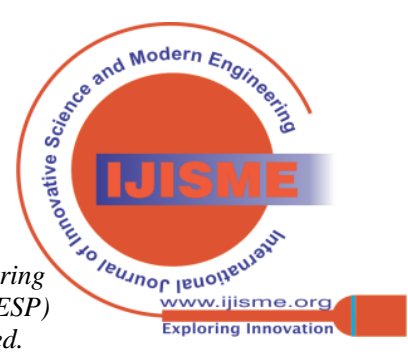


Table II.4.Concrete compression damage parameters

\begin{tabular}{|c|c|}
\hline \multicolumn{2}{|c|}{ Damage in concrete due to compression } \\
\hline Damage parameter $\left(\mathrm{N} / \mathrm{mm}^{2}\right)$ & Inelastic strain \\
\hline 0 & 0 \\
\hline 0.9 & 0.011 \\
\hline
\end{tabular}

Table II.5. Tensile behavior parameters of steel

\begin{tabular}{|c|c|}
\hline \multicolumn{2}{|c|}{ Tensile behavior } \\
\hline Yield Stress $\left(\mathrm{N} / \mathrm{mm}^{2}\right)$ & Cracking strain \\
\hline 1.35 & 0 \\
\hline 1.92 & 0.001604 \\
\hline 0.02 & 0.002086 \\
\hline
\end{tabular}

\subsubsection{Boundary condition}

Fixed support were assigned at bottom surface of the column of the joint model. On top column surface, restrain YASSYM (U1=U2=U3=UR2=0) was applied. Restrains, XSYMM and ZSYMM, which prevent motion in the $\mathrm{x}$ and $\mathrm{z}$ axis on all beam faces of joint models were applied (U1=UR2 $=\mathrm{UR} 3=0$ and $\mathrm{U} 2=\mathrm{UR} 1=\mathrm{UR} 2=0$ ).

In the corner joint is applied a displacement in two separate steps in the negative $y$-direction for the first and positive $\mathrm{x}$-direction in the second according to the axis orientation presented in the respective figures showing the concerned joints on both beams found on $\mathrm{X}-\mathrm{Z}$ and $\mathrm{Y}-\mathrm{Z}$ planes of values $150 \mathrm{~mm}$ and $125 \mathrm{~mm}$ and $90 \mathrm{~mm}$ in the $\mathrm{X}$ -

\section{FE ANALYSIS}

The finite element analysis results of the RC beamcolumn joint under loading are shown using forcedisplacement diagrams, crack paths and ultimate loads. Also, the validity of the finite element model was assessed through comparison of the following parameters:
Y plane for lateral loading to simulate a static loading condition that causes the reinforced structural model to arrive its plastic phase and present crack patterns and damage areas as well as in an earthquake event. In the same line, displacements of the same values are applied to the interior and edge joints except for the lateral displacement. A beam in a structure under static loading is subjected to bending that is why displacement rather force is used to better express the effects.

Loading is introduced in the corner joint model as a pressure load on the top column surface to simulate compressive axial force and maintained at a constant value of $9 \mathrm{~N} / \mathrm{mm} 2$ throughout the analysis procedures.

- Plastic deformations in beam

- $\quad$ Cracking in the beam

The results of the analysis of the corner joint connection under static load and with lateral load are reported in this section. The reinforcements are as shown in Figure III.1 and Figure III.2 As previously mentioned, the Damage Plasticity model for concrete was used to conduct simulation.
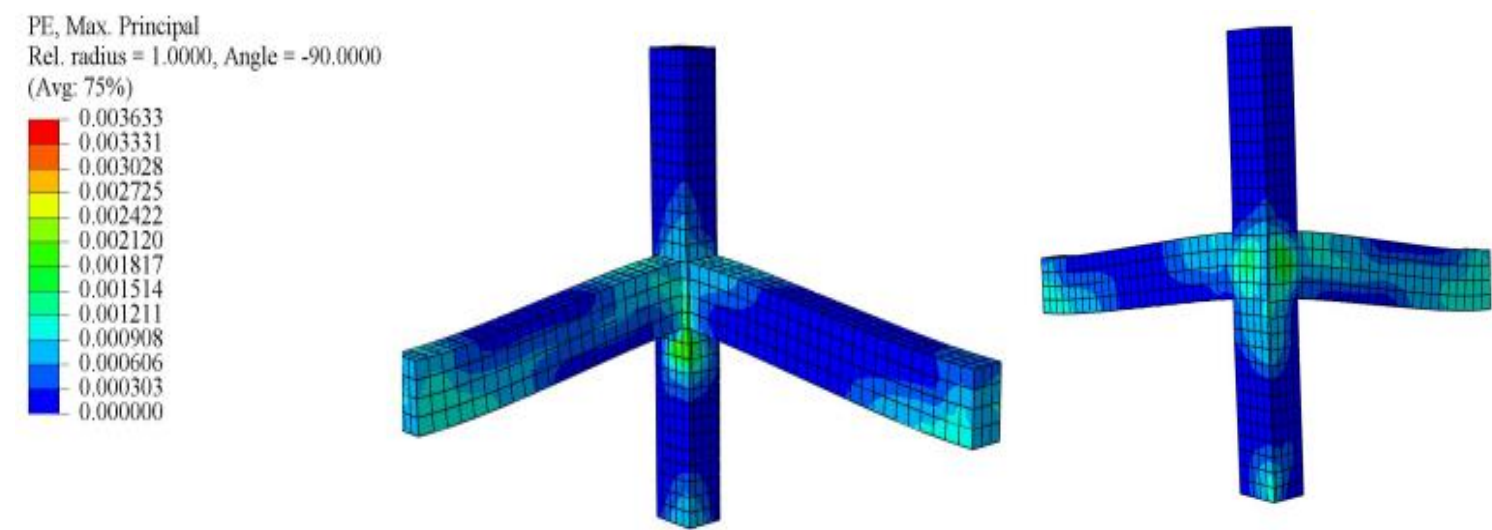

(a) Unconfined model

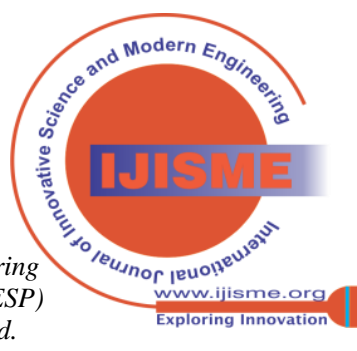


Finite Element Method Analysis Applied to the Study of a Corner Joint in Reinforced Concrete Structures
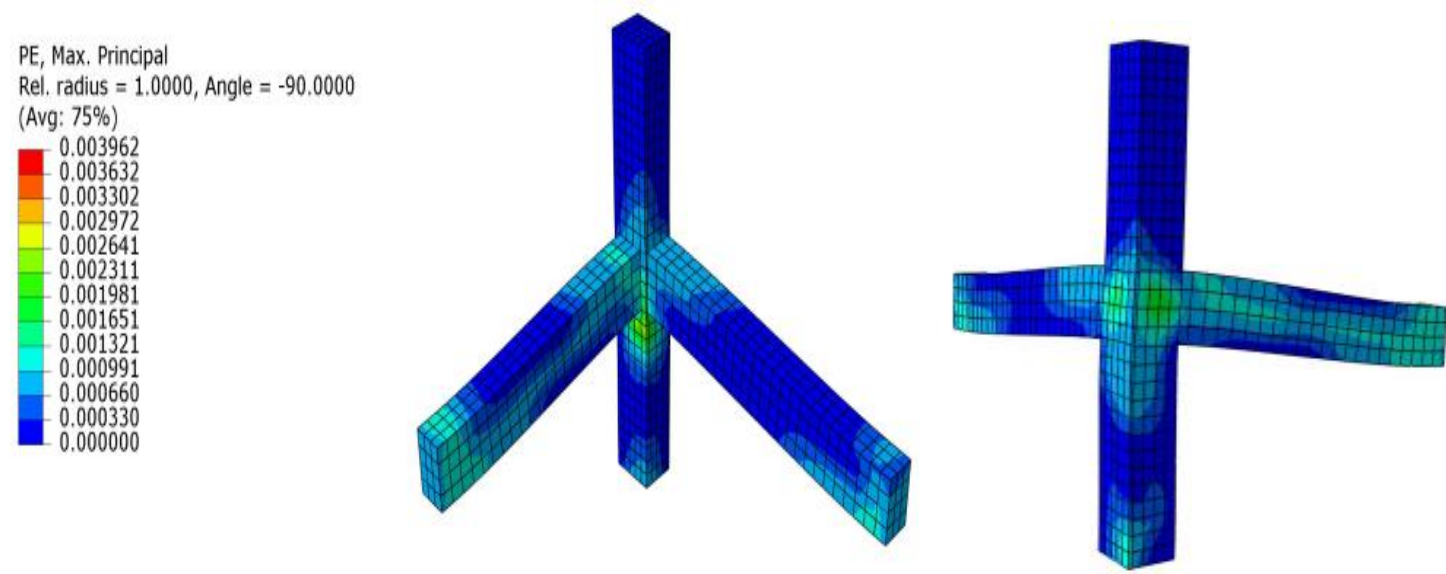

(b) Confined model

Figure III.1. Plastic tensile deformations

PE, Min. Principal

Rel. radius $=1.0000$, Angle $=-90.0000$

(Avg: 75\%)
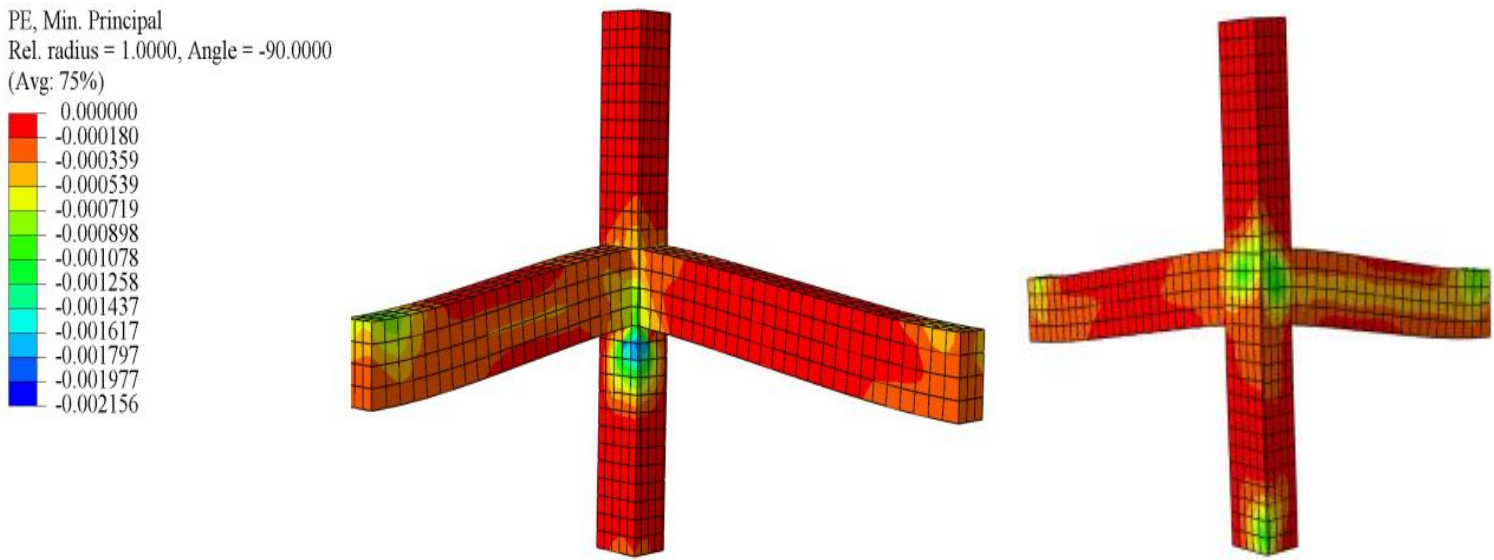

(a) Unconfined model

PE, Min. Principal

Rel. radius $=1.0000$, Angle $=-90.0000$

(Avg: 75\%)
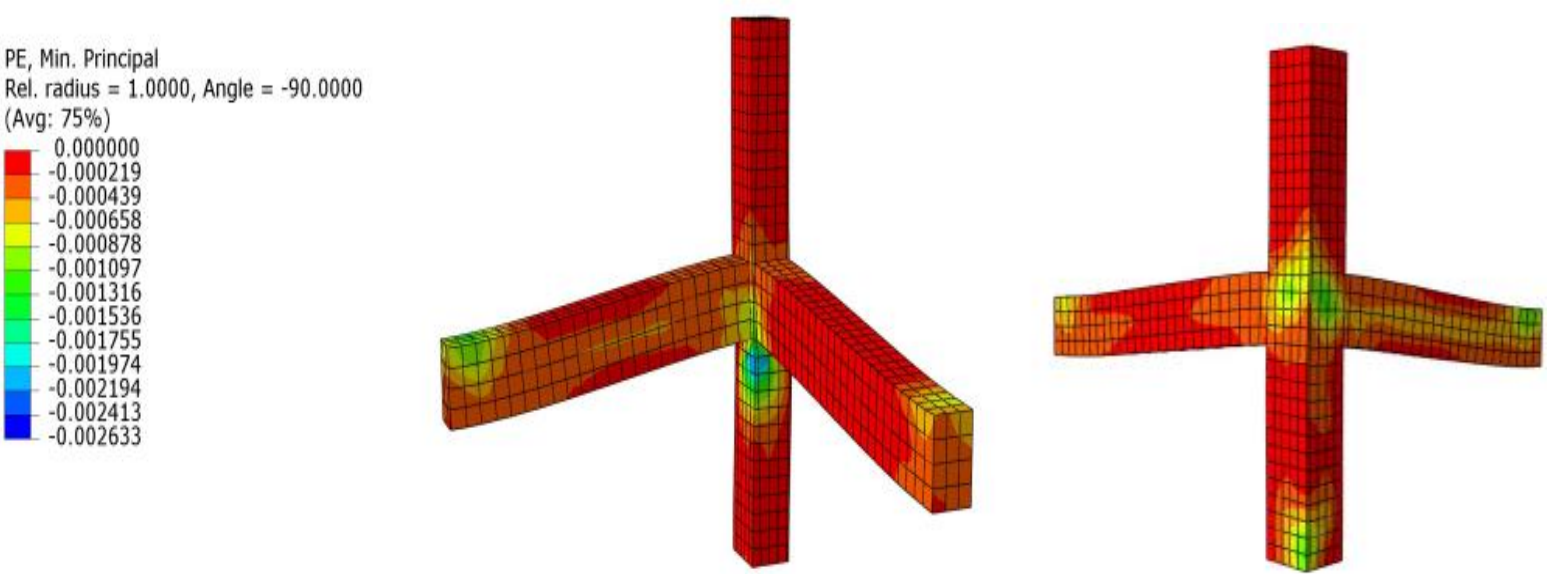

(b) Confined model

Figure III.2. Compressive plastic deformations

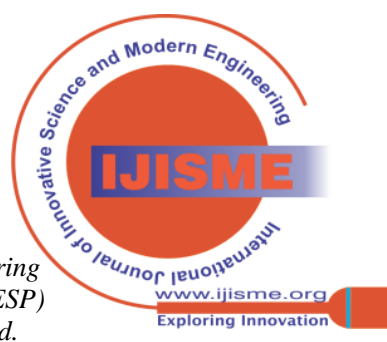



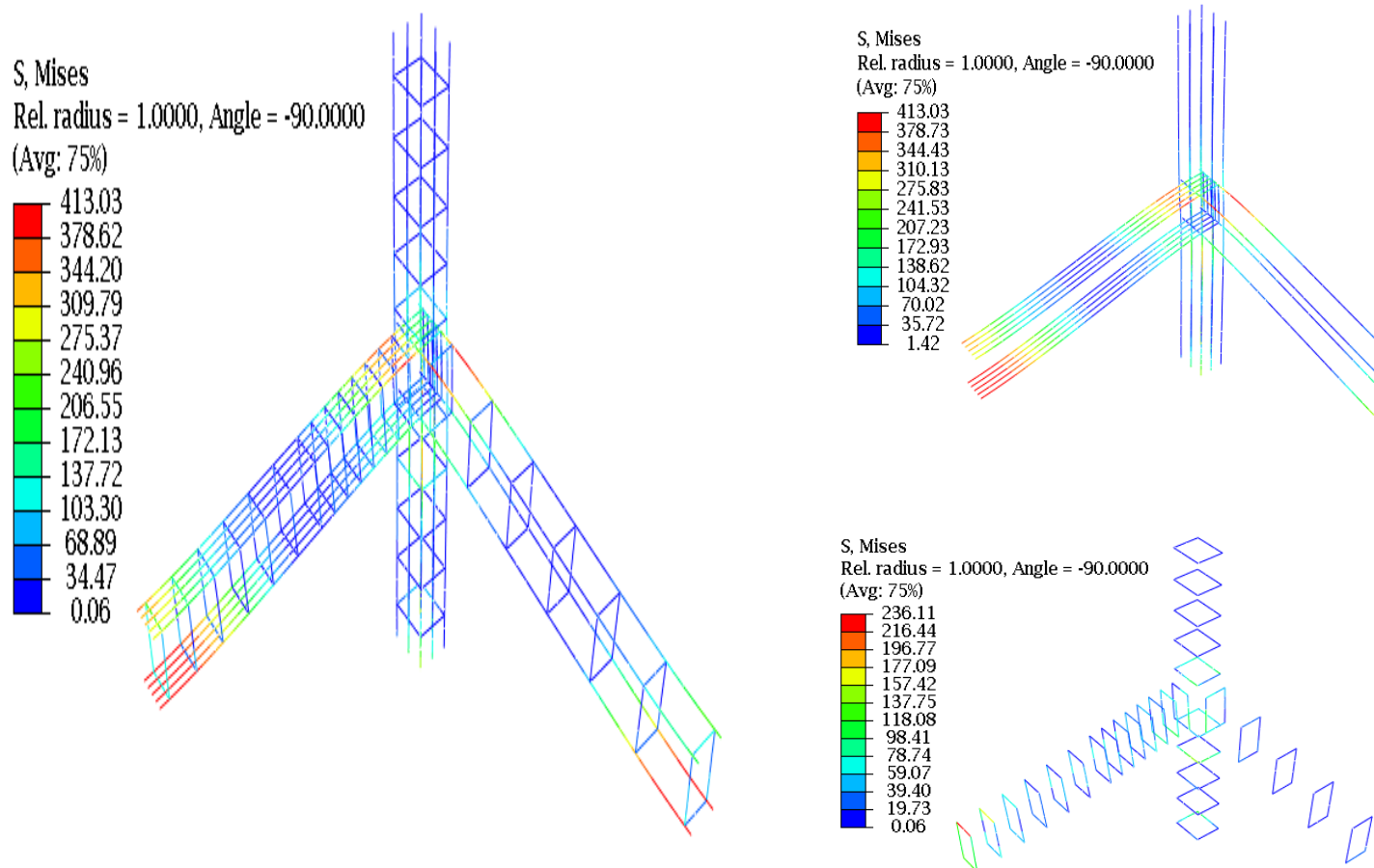

(a) Unconfined model
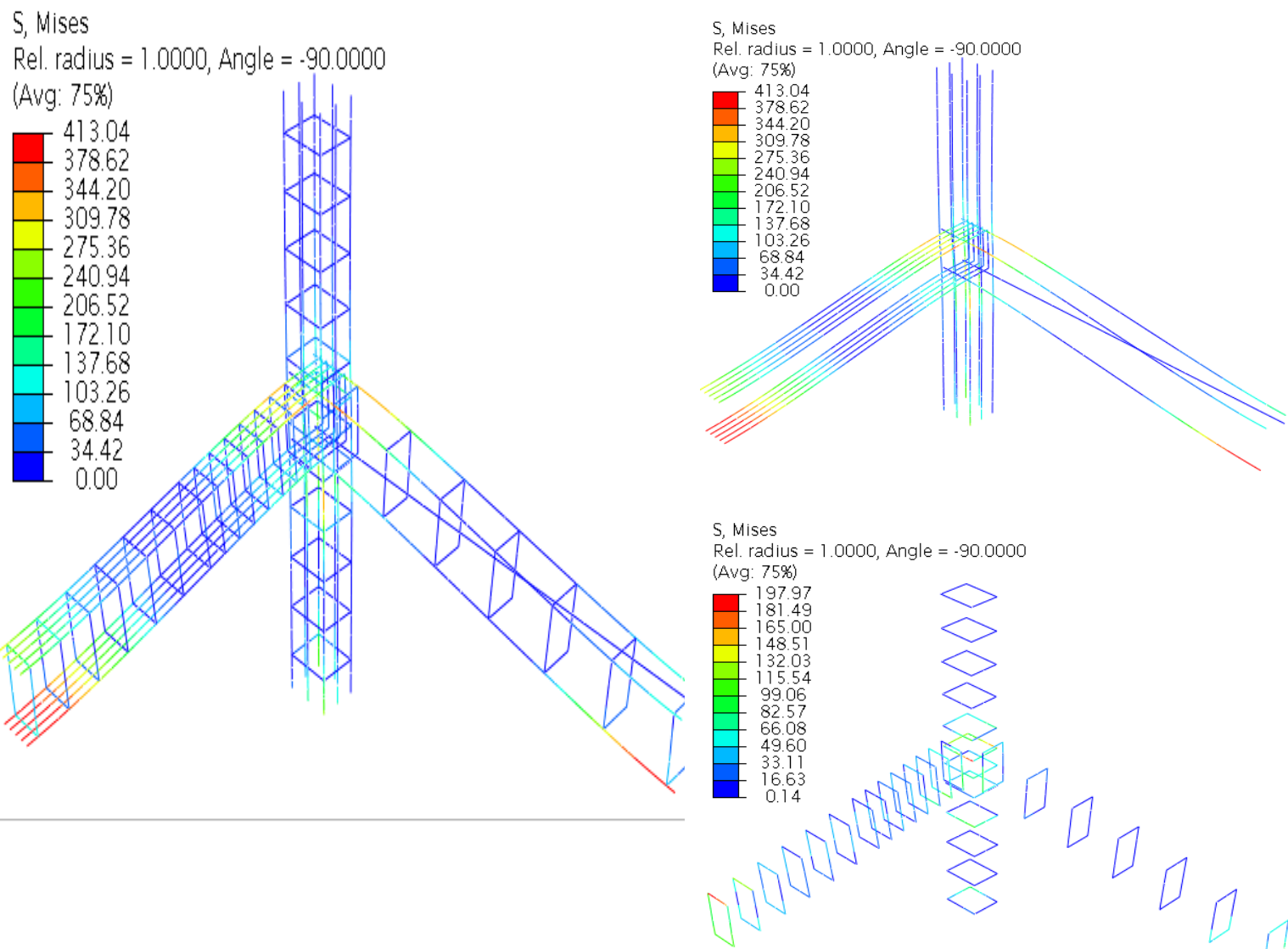

(b) Confined model

Figure III.3. Mises stresses in steel reinforcements

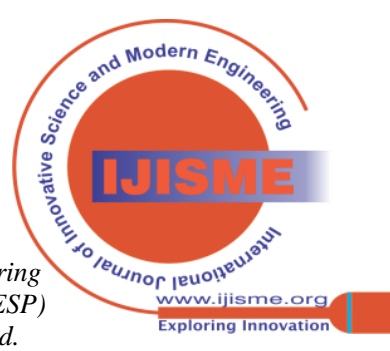


Finite Element Method Analysis Applied to the Study of a Corner Joint in Reinforced Concrete Structures

S, Mises

Rel. radius $=1.0000$, Angle $=-90.0000$

(Avg: 75\%)

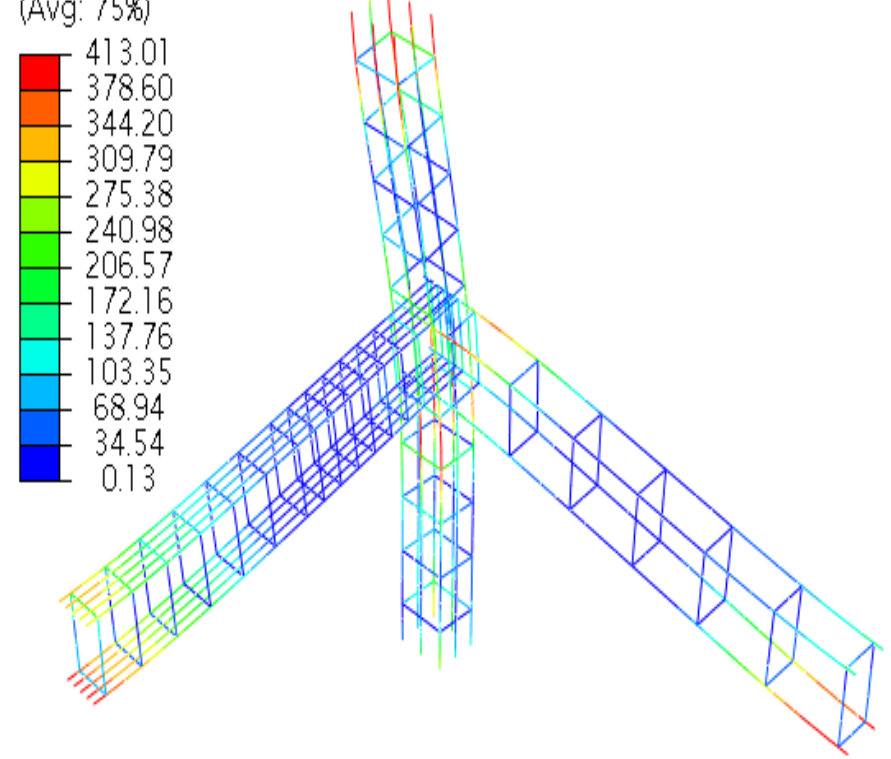

5. Mises
Rel. radius $=1.0000$, Angle $=-90.0000$

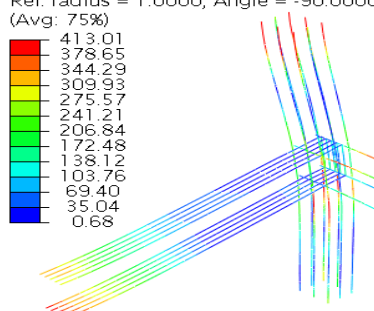

S, Mises

$s=1.0000$, Angle $=-90.0000$

(Avg: 75\%)

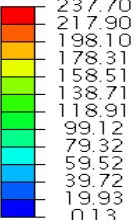

(a) Unconfined model

S, Mises

Rel. radius $=1.0000$, Angle $=-90.0000$

(Avg. 75\%)

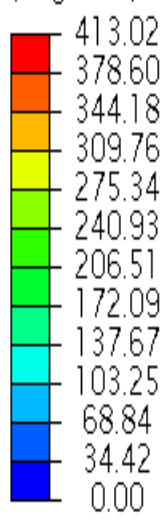

(b) Confined model

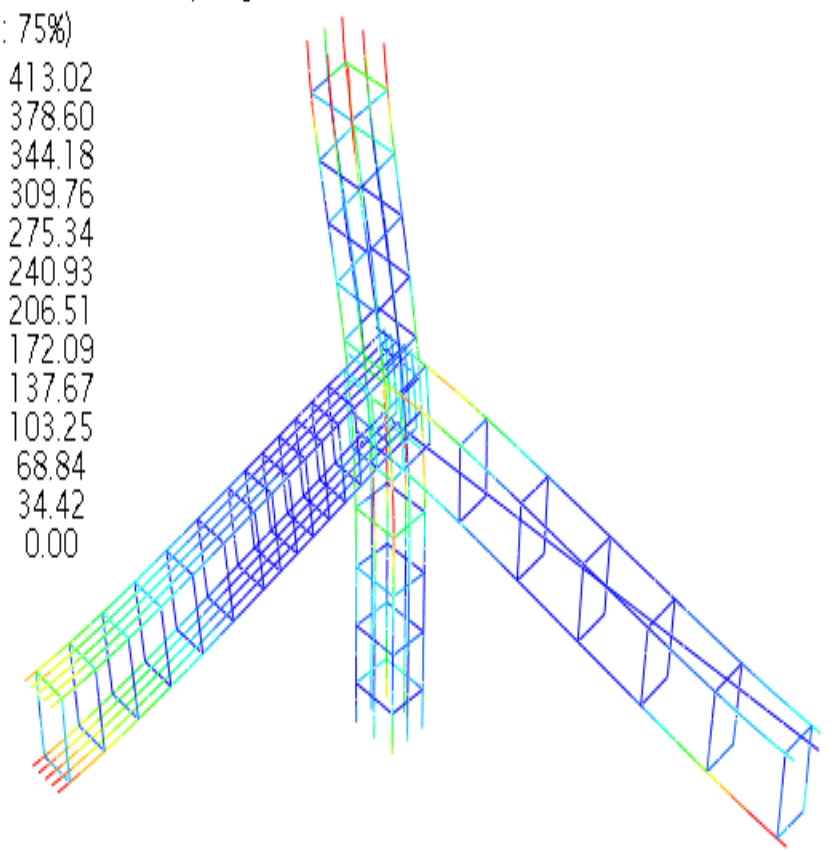

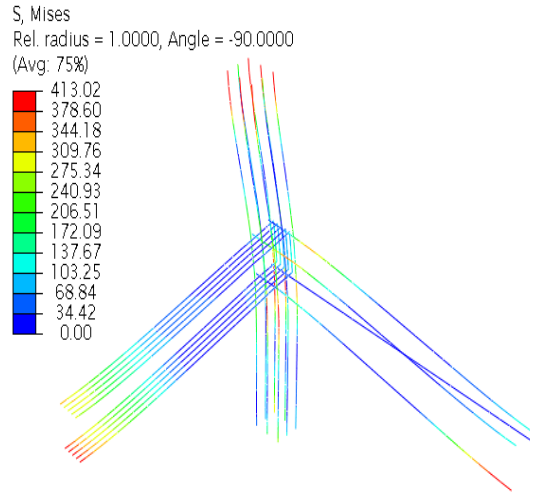

S. Mises

Rel radius $=1.0000$, Angle $=-90.0000$ (Avg: 75\%)

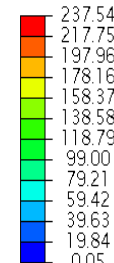

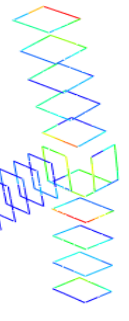

$\theta$

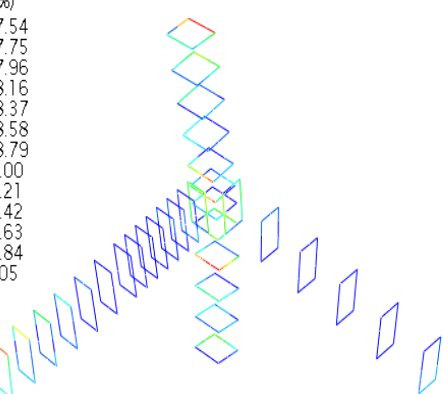

Figure III.4. Mises stresses in steel reinforcements

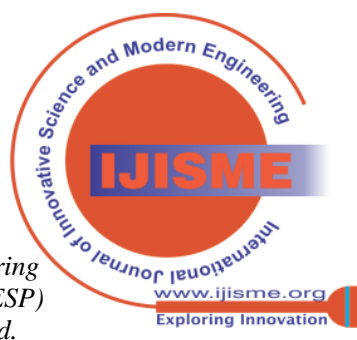


Force-displacement graph for a coner joint under static loading

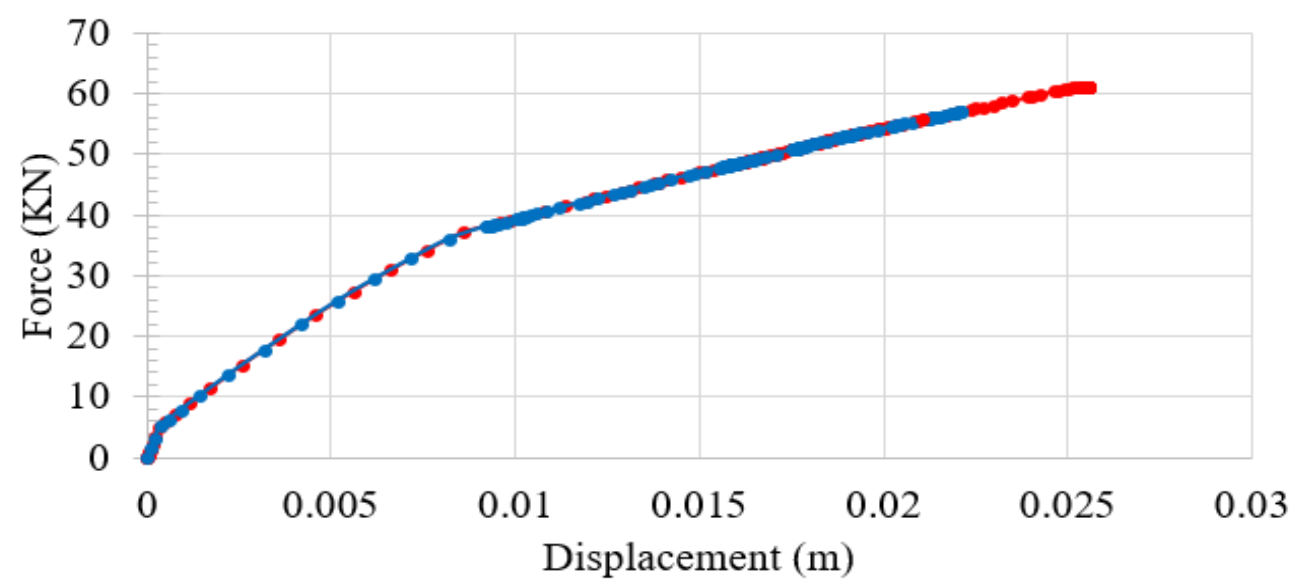

$\rightarrow$ Confined $\rightarrow$ Unconfined

Figure III.5. Force-displacement diagram

Stress-strain diagram for corner joint under static loading

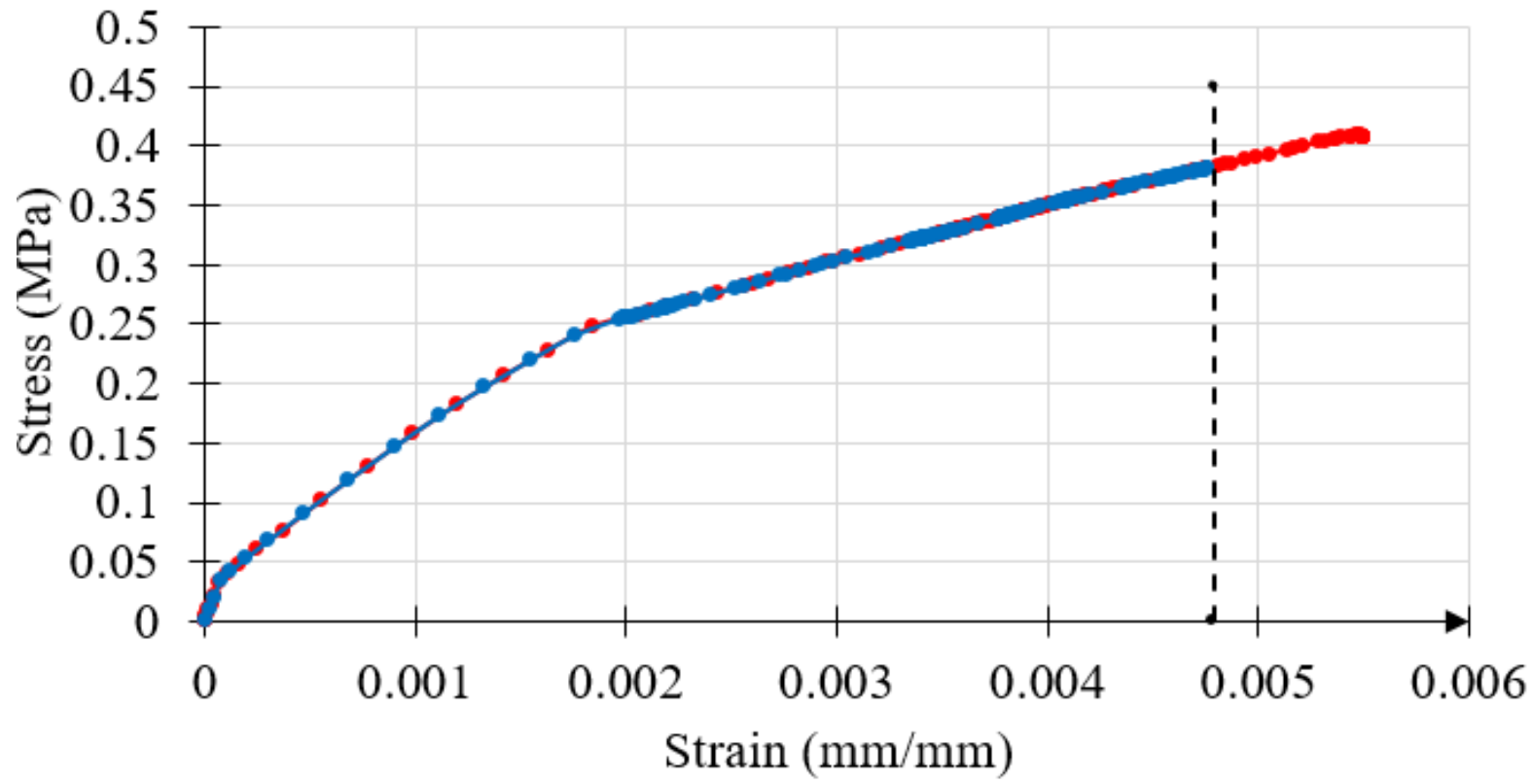

$\bullet$ CONFINED $\rightarrow$ UNCONFINED

Figure III.6. Stress-strain diagram

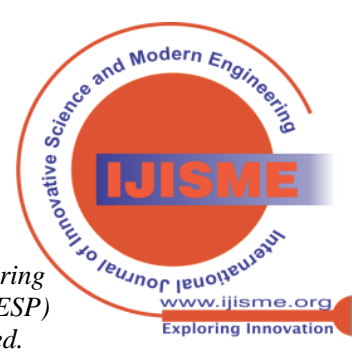




\section{Force-displacement graph for a corner joint with lateral} displacement

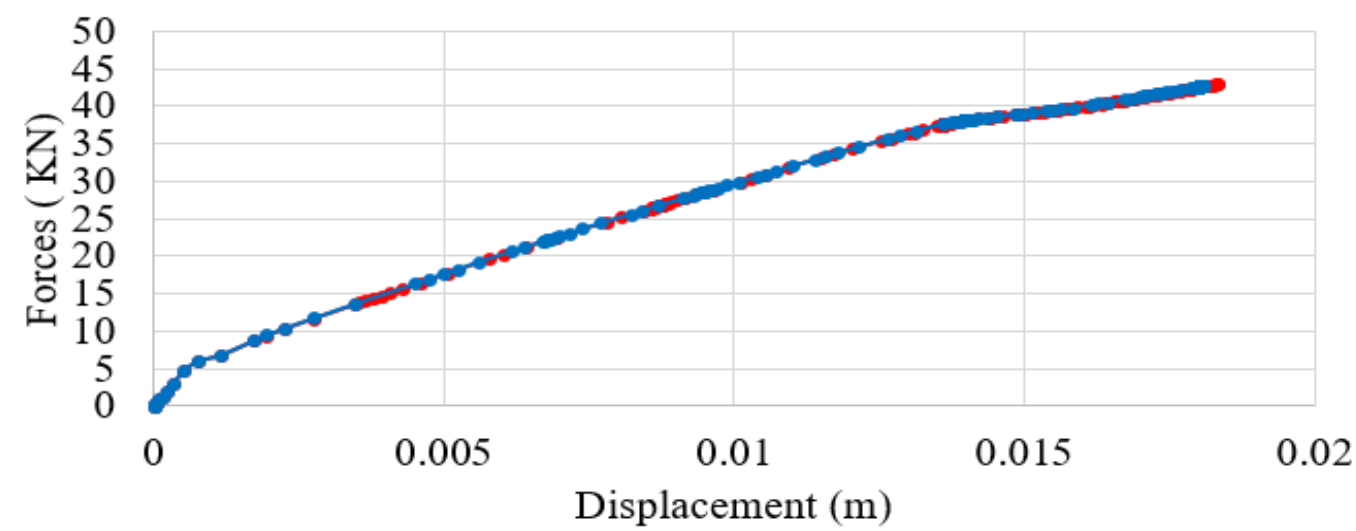

$\rightarrow$ Confined

$\rightarrow$ Unconfined

Figure III.7. Force-displacement diagram of corner joint with lateral displacement

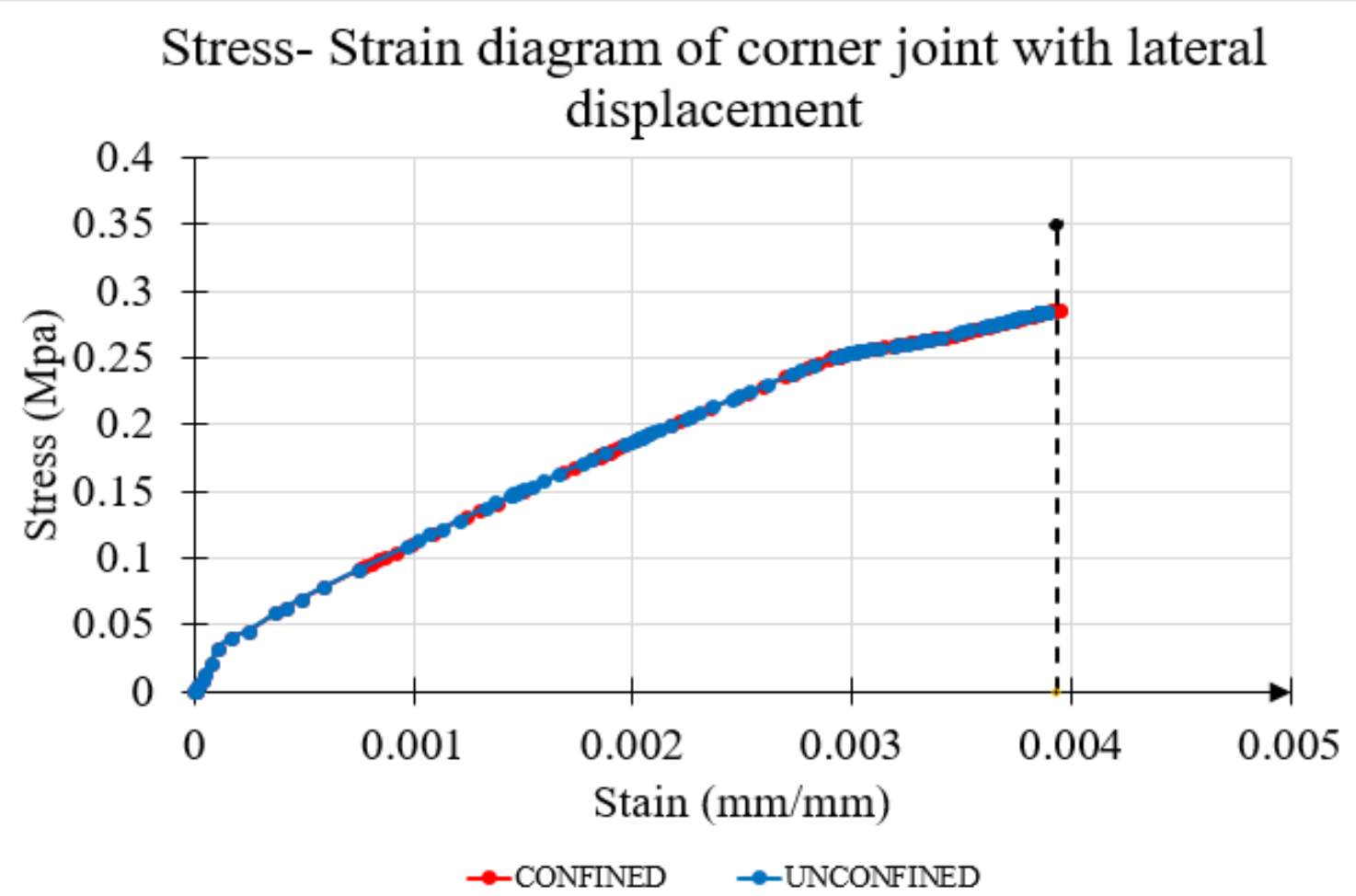

Figure III.8. Stress-strain diagram for corner joint with lateral displacement

Inelastic displacements result in tensile yielding of longitudinal reinforcement followed by compressive loading that imposes large demands on the bar in compression. Deformations shown in Figure III.1 and Figure III.2 explicitly represent the resistance of both models to deformations. The confined model deforms more than the unconfined model. This is reasonable because of the presence of transverse reinforcements at the core of the connection contributing in truss resisting procedure. The difference between these deformation values is also accounted for by the model proposed by Paulay and Priestley (1992). In their work, they explained joint shear strain contributes significantly to the total drift. The same phenomenon is observed when a lateral load is applied to both FE models in correspondence with the results obtained in the work presented by Prof. Dr.-Eng. Rolf Eligehausen Mitberichter, Prof. Dr.-Eng. Habil Manfred Bischoff and Prof. Dr.-Eng. Jan Hofmann (2013). In their work after performing five tests on RC beam-column connections, which were poorly detained and at full sale. The results clearly confirmed how vulnerable non-seismically designed joints subjected to seismic loads could be.

Looking at tensile stress propagation in the joints under lateral loading, the above results are matched which verify our models for plasticity. The zones under tension are all in the elastic range.

Blue Eyes Intelligence Engineering and Sciences Publication (BEIESP) (C) Copyright: All rights reserved.

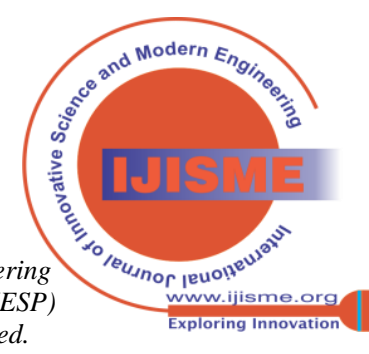


The force displacement diagram above (Figure III.5 ) is an illustration of the improved behavior of the joint due to a relatively small amounts of transverse joint reinforcement. Greater deformations are possible as the ductility behavior of the structural element is improved. Nevertheless, ductile behavior in the case of lateral displacement is seriously compromised even though the confined model performs better. Strains in the models when under pure static loading exceed $0.005 \mathrm{~mm} / \mathrm{mm}$ meanwhile in the lateral loading phase is less than $0.004 \mathrm{~mm} / \mathrm{mm}$.
The Mises stresses in the reinforcements for both loading conditions in the confined and unconfined models are the same. The lateral displacement applied to the joint induces bending at the center of the joint. Column longitudinal reinforcements bear most of the bending moment. The stresses in the beam longitudinal reinforcements are induced by the static loading and the lateral displacement in the direction of loading.
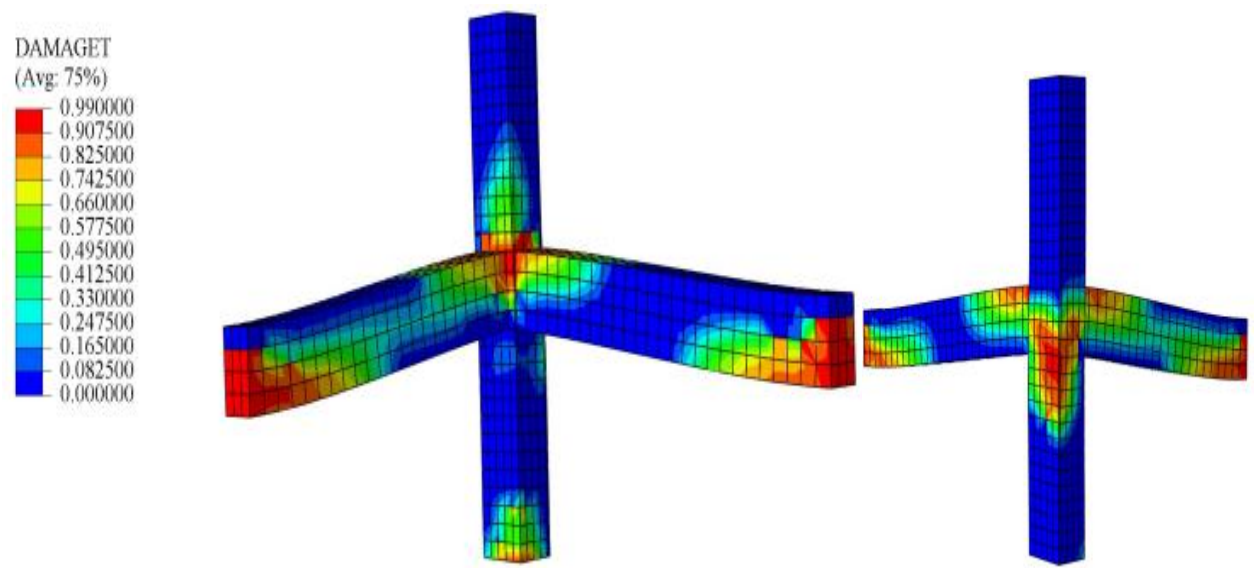

(a) Unconfined model
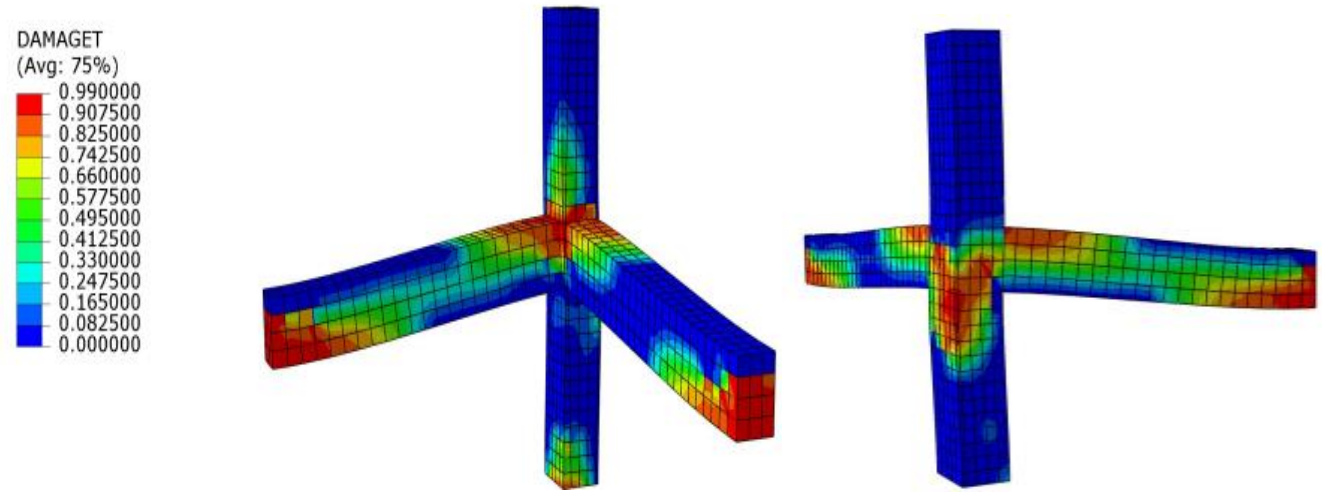

(b) Confined model

Figure III.9. Crack pattern under tensile stresses

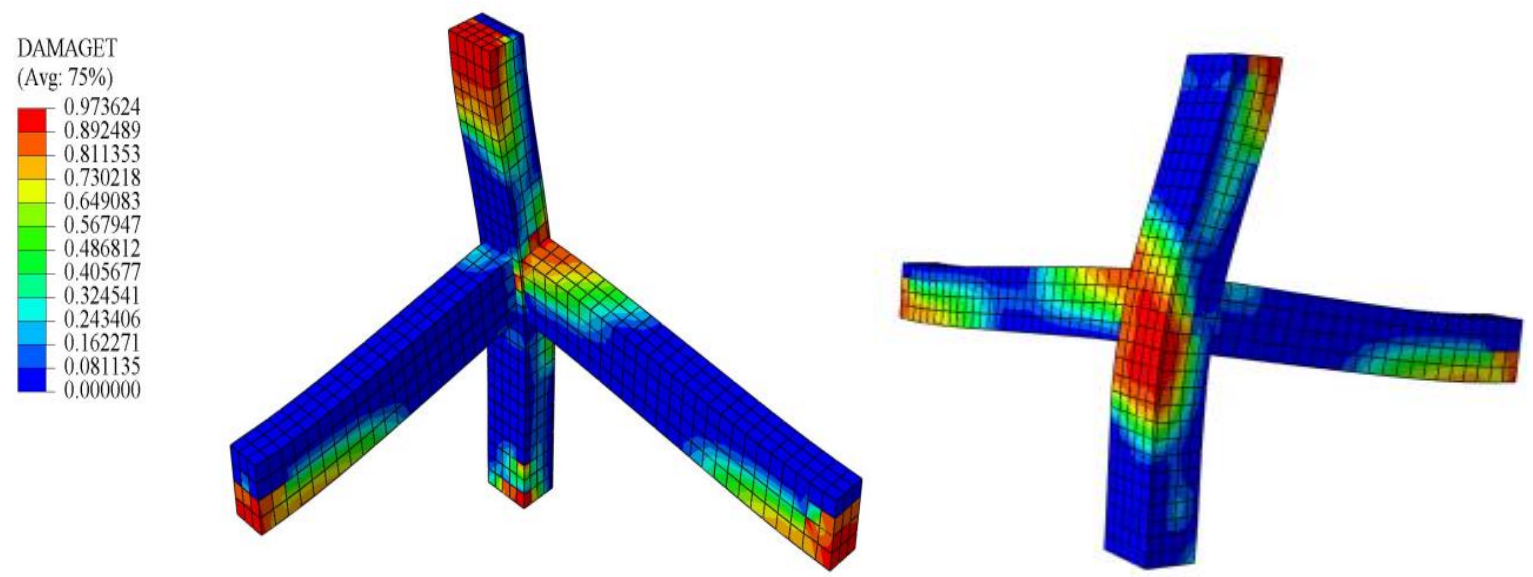

(a) Unconfined model

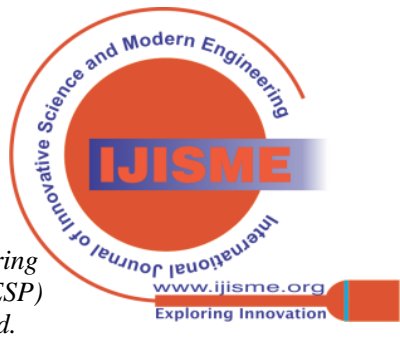


Finite Element Method Analysis Applied to the Study of a Corner Joint in Reinforced Concrete Structures
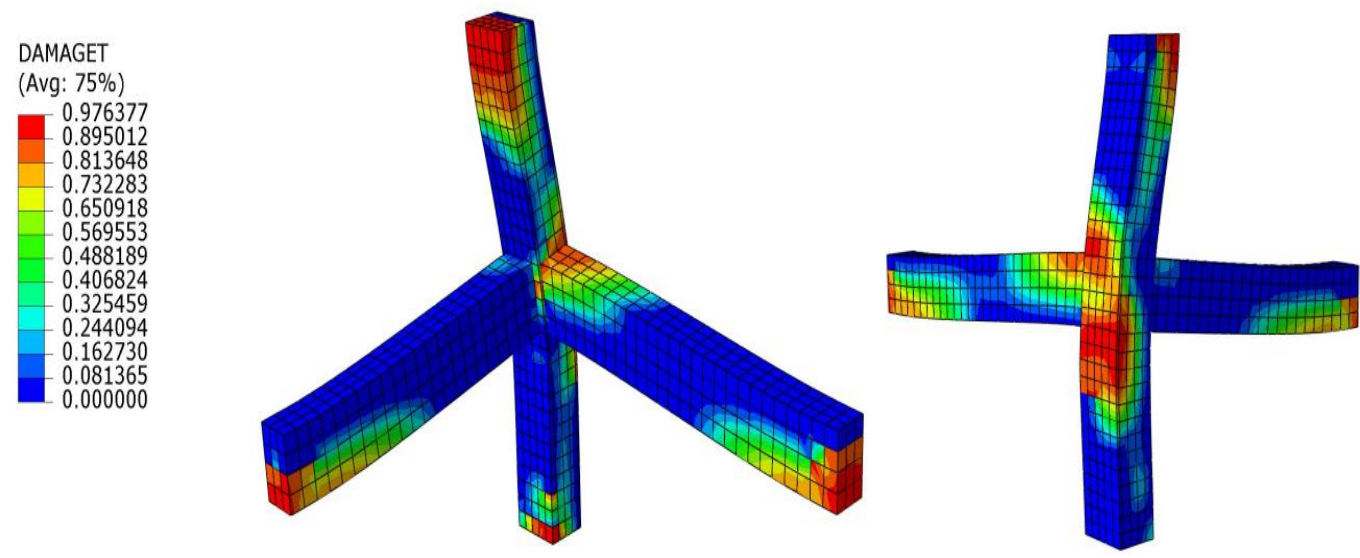

(b) Confined model

Figure III.10. Concrete tension damage
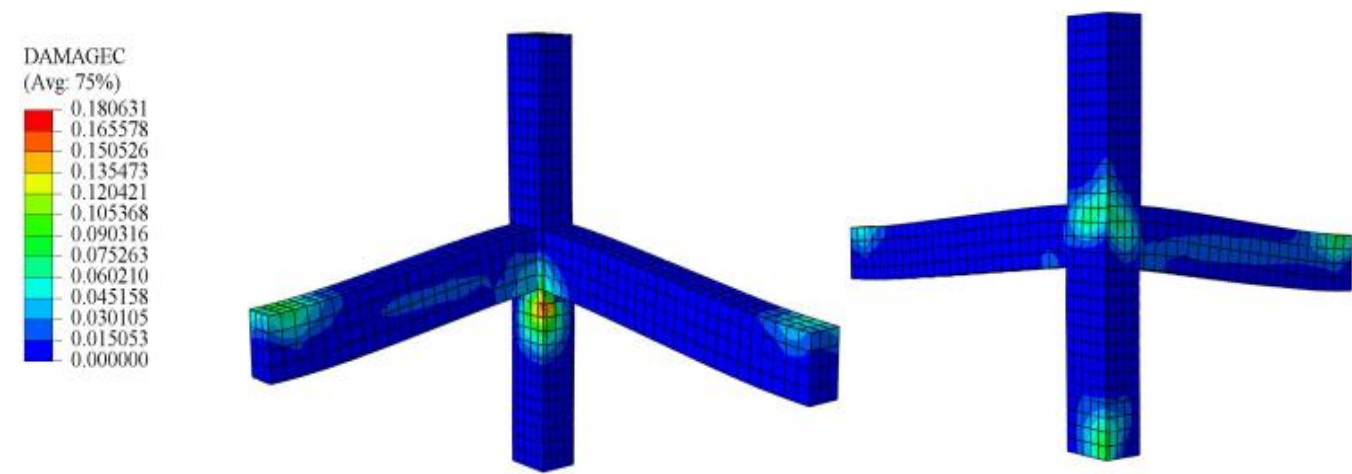

(a) Unconfined model
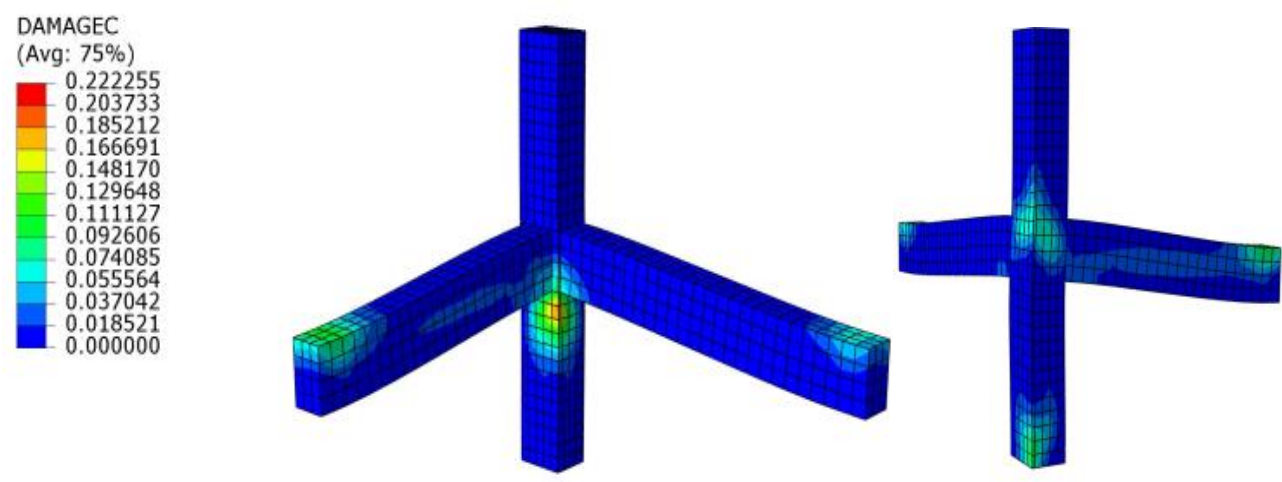

(b) Confined model

Figure III.11. Illustration of compressive damage
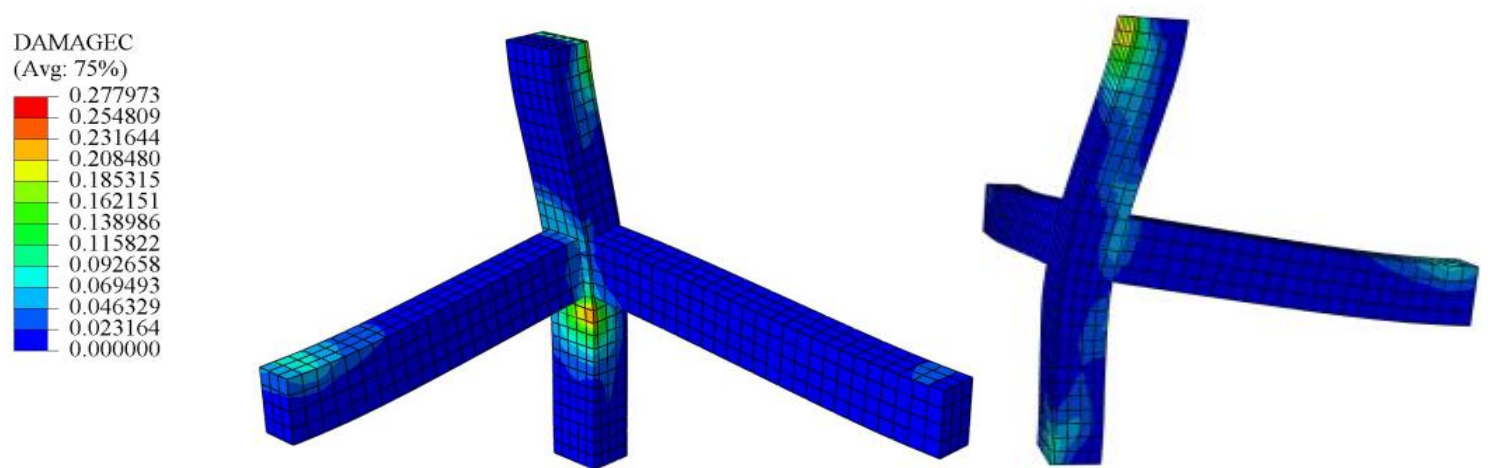

(a) Unconfined model 

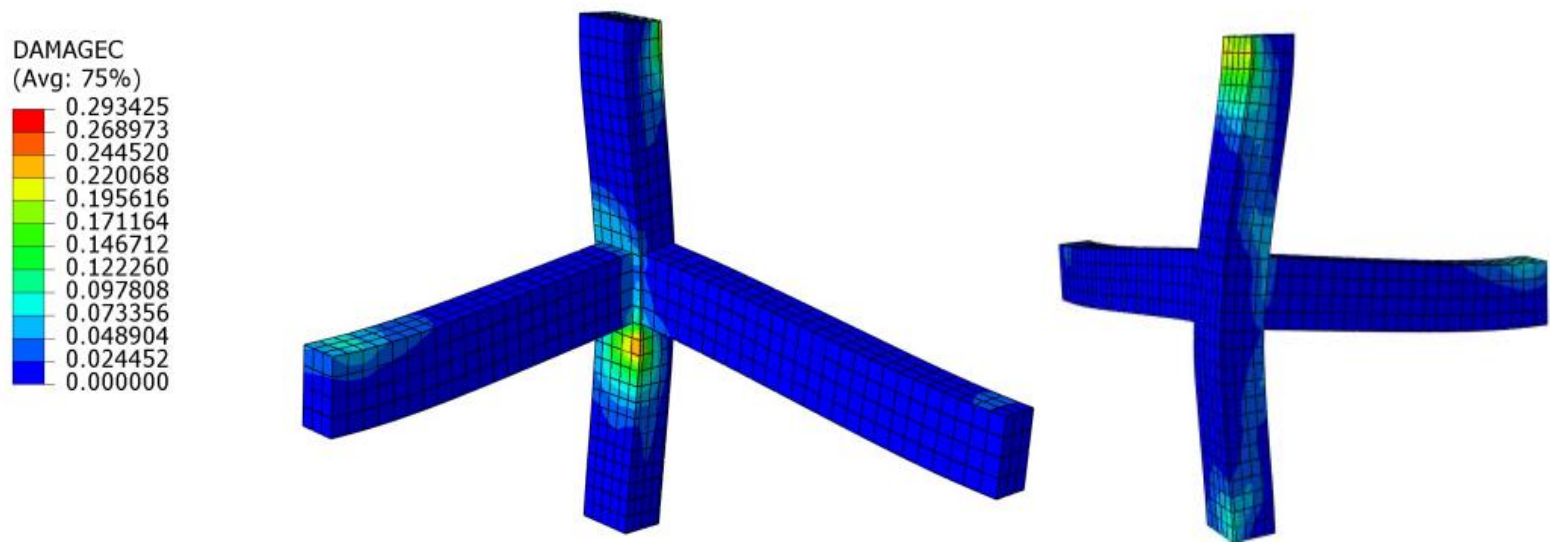

(b) Confined model

Figure III.12. Concrete compression damage

Figure III.13 shows the crack pattern in a corner joint under monotonic loading as an experimental result. The experiment was conducted by M. Allam, Hazem M.F. Elbakry and Israa S.E. Arab (2018). Looking at the Finite Element Analysis results obtained and shown in Figure III.9, we realize that the cracking pattern obtained by $\mathrm{M}$. Allam et al. is conveniently predicted by both the unconfined model and the confined model.

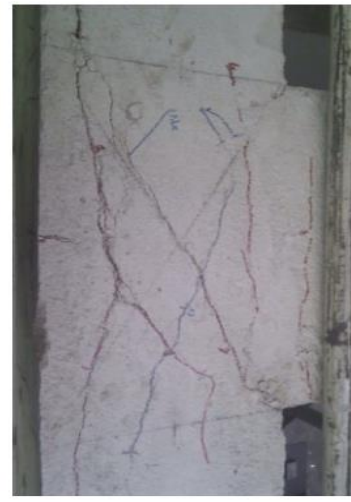

Figure III.13. Cracking pattern in a corner joint under (C. Del Vecchio, M. Di Ludovico, A. Prota and G. Manfredi (2015))

M. J. N Priestley (1995) already had a theory on the failure mode of an exterior corner joint. In his work, M. J. N Priestley states that, for a situation in which beam reinforcements are bent down into the joint as it is the case in both confined and unconfined models, joint cracking occurs first due to positive moments in beams, since, in that direction of response, there is a reduction in axial force. Of course, the joint under study was a plane frame exterior corner joint, however the theory is true for both planes $(\mathrm{X}-\mathrm{Z}$ and $\mathrm{Y}-\mathrm{Z}$ ) in the space frame models which constitute the case study of this piece work. Still according to Priestley, in a multi-story building, cracking under negative moment is delayed because of very high variations of the axial force in exterior corner joints. Results from M. J. N Priestley (1995) experiments concluded that horizontal dilatation of the joint has a higher tendency to occur during crack development. This curves the cover concrete at the back of the joint leading to cracking (in the vertical direction) on the weak plane as illustrated by the models shown in Figure III.14. This occurs at the line of column reinforcement. It is mostly the case if the hooks of the beam reinforcements lie in the same plane.
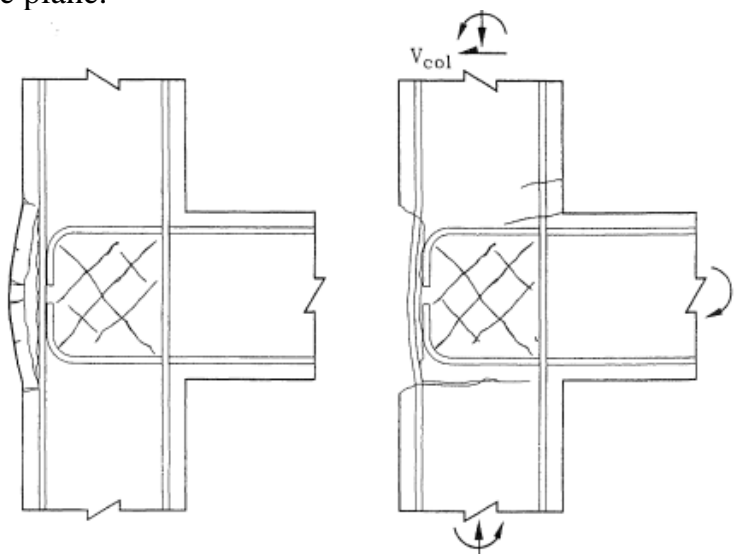

Figure III.14. Breakdown of unreinforced exterior corner joint; Cracking at the back of the joint on the left; Loss of joint integrity on the right

Both finite element models (confined and unconfined) do not only match the predictions of Priestley (1995) and the experimental results of $\mathrm{M}$. Allam et al. but also do they confirm Paulay and Priestley (1992) joint model according to which, ductility of the beam-column connection in RC elements is increased not only by providing shear reinforcements transversally in in the center of the joint but by providing for adequate longitudinal beam reinforcement anchorage. This is demonstrated in Figure III.10 as the values of stresses are almost the same at each stress level for both the confined and the unconfined joint models. The orange and red elements are the most tensioned, zones where cracking is most severe and the blue elements are stress free.

For crack patterns caused by the compression field (compression damage), Figure III.11 illustrates that, because of the presence transversal reinforcements for confinement, compressive strength of the confined model is higher compared to that of the unconfined model. Blue elements are stress free mean while the red elements are the most compressed. The green elements are compressed but still in the elastic field.

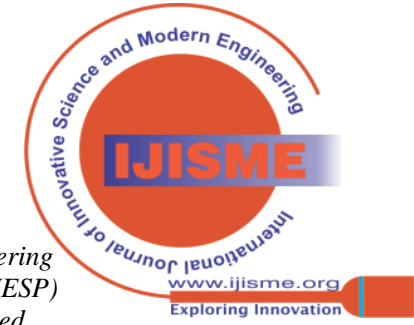


Figure III.10 a and b show crack patterns in unconfined and confined joints due to tensile stresses under lateral loading. Severe cracking is observed at the red zones. These elements have exceeded ultimate stress and strength values displacement is remarkable and failure at the joint is verified from experimental results shown in Figure III.13.

Under compression damage, cracking pattern is different. In Figure III.12 compressive crack pattern can be seen for both models. In either models, most of the elements are stress free (blue elements). Nevertheless, the joint core is still subject to compression stresses. These stresses lead to induced diagonal compression shear stresses in the center core region of the joint resisted by diagonal concrete strut as proposed by Paulay and Priestley (1992).

\section{CONCLUSION}

The analysis results of this study have endeavored to present the results obtained from the nonlinear finite element analysis of the above numerical models that describes the nonlinear shear behavior of poorly designed (unconfined) and detailed (confined) reinforced concrete corner joint for comparison with experimental and analytical results. Comparing finite element results for each loading situation enabled the verification of the mechanical behavior transversal shear reinforcements hampers the ductile behavior of the corner joint during lateral loading. Hence, improvement in the mechanical behavior of the corner joint during a seismic event is to be checked for through the study of other parameters like anchorage of the beam longitudinal reinforcements for both beams framing in the joint or the bond stress.

\section{REFERENCES}

1. Abebe, B. H., \& Lee, J. S. (2019). Incorporation of torsional \& higher-mode responses in displacement-based seismic design of asymmetric RC frame buildings. Applied Sciences (Switzerland), 9(6). https://doi.org/10.3390/app9061095

2. Abhyuday, T. (2017). Fundamentals of direct displacement based design procedure - A brief introduction. Disaster Advances, 10(6), $40-43$.

3. ACI 318-14. (2014). ACI 318-14 - Building Code Requirements for Structural Concrete. In American Concrete Institute.

4. ACI committee 318. (2011). ACI 318-11 Building Code Requirement. 1-509. www.concrete.org/committees/errata.asp

5. Allam, S. M., Elbakry, H. M. F., \& Arab, I. S. E. (2018). Exterior reinforced concrete beam column joint subjected to monotonic loading. Alexandria Engineering Journal, 57(4), 4133-4144. https://doi.org/10.1016/j.aej.2018.10.015 Reynolds, J. H., ALMEIDA, F. F. M. D. E., de Almeida, F. F. M., Hasui, Y., de Brito Neves, B. B., Fuck, R. A., Oldenzaal, Z., Guida, A., Tchalenko, J. S., Peacock, D. C. P., Sanderson, D. J., Rotevatn, A., Nixon, C. W., Rotevatn, A., Sanderson, D. J., ... Junho, M. do C. B. (2013).. Journal of Petrology, 369(1), 1689-1699. https://doi.org/10.1017/CBO9781107415324.004

7. Baker, J. W. (2007). Measuring bias in structural response caused by ground motion scaling. Pacific Conference on Earthquake Engineering, 056, 1-6. https://doi.org/10.1002/eqe

8. Bhaskar, M. G. B. (2018). Analysis of Beam-Column Joint subjected to Seismic Lateral Loading. International Journal for Research in Applied Science and Engineering Technology, 6(6), 330-347. https://doi.org/10.22214/ijraset.2018.6052

9. Conference, I., Structural, E., October, E., \& Francisco, S. (2009). COMPREHENSIVE SERIES OF TESTS ON SEISMIC PERFORMANCE OF REINFORCED CONCRETE BEAMCOLUMN JOINTS Hitoshi Shiohara 1 and Fumio Kusuhara 1.1-11. leading to failure. Still on the same figure, column of the corner joint. It came forth that, the presence of the

6. Amaral, G., Bushee, J., Cordani, U. G., KAWASHITA, K.,

10. Cotsovos, D. M., \& Kotsovos, M. D. (2008). Cracking of rc beam/column joints: Implications for practical structural analysis and design. Structural Engineer, 86(12), 33-39.

11. Crisafulli, F. (1997). Thesis_Fulltext.Pdf (p. 395).

12. De Risi, M. T., Ricci, P., \& Verderame, G. M. (2016). Role of beamcolumn joints in the seismic response of non-conforming RC frames. The New Boundaries of Structural Concrete, September.

13. Del Vecchio, C., Di Ludovico, M., Prota, A., \& Manfredi, G. (2015). Advanced numerical modelling for damage analysis of RC structures: A case study on beam-column joints.

14. Delle, T., \& In, T. (2011). TRIESTE.

15. Dunn, A. M., Hofmann, O. S., Waters, B., \& Witchel, E. (2011). Cloaking malware with the trusted platform module. In Proceedings of the 20th USENIX Security Symposium (pp. 395-410).

16. Filippou, F. C. (2015). Mechanics and Materials Finite Element Analysis of Reinforced Concrete Structures. July.

17. Genesio, G. (2012). Seismic Assessment of RC Exterior BeamColumn Joints and Retrofit with Haunches Using Post-Installed Anchors.

18. Hanke, K. (2007). About The Author About the Author (Issue 1949). McGraw-Hill Education.

19. Hejabi, H., \& Kabir, M. Z. (2015). Analytical model for predicting the shear strength of FRP-retrofitted exterior reinforced concrete beam-column joints. Scientia Iranica, 22(4), 1363-1372.

20. Iskef, A. E., Gatuingt, F., Ragueneau, F., Giry, C., Iskef, A. E., Gatuingt, F., Ragueneau, F., \& Giry, C. (2017). Modeling the nonlinear mechanical response of reinforced concrete structures by simplified approaches To cite this version : HAL Id : hal-01623728.

21. Jankowski, R. (2007). Theoretical and experimental assessment of parameters for the non-linear viscoelastic model of structural pounding. Journal of Theoretical and Applied Mechanics (Poland), 45(4), 931-942.

22. Jankowski, R., \& Mahmoud, S. (2016). Linking of adjacent threestorey buildings for mitigation of structural pounding during earthquakes. Bulletin of Earthquake Engineering, 14(11), 30753097. https://doi.org/10.1007/s10518-016-9946-z

23. Kaliluthin, A. K., Kothandaraman, S., \& Ahamed, T. S. S. (2015). A Review on Behavior of Reinforced Concrete Beam-Column Joint. International Journal of Innovative Research in Science, Engineering and Technology, 2014(4), 11299-11312.

24. Kumar, P. (2020). A Review on Pre-Engineered Building design of an Industrial Warehouse. Proteus Journal, 11(06), 1484-1488. https://doi.org/10.37896/pj11.06/001

25. Kumari, B. (2010). Finite Element Modelling of Reinforced Master of Engineering in Finite Element Modelling of Reinforced. 109.

26. Lavanya Prabha, S., Sreekumar, N., Arthi, R., Balamurali, I., \& Pradeep, P. (2018). Study of Beam Column Joint With Different Reinforcement Detailing State of the Art Review. International Journal of Scientific \& Engineering Research Volume, 9(2), 353361.

27. Li, B., \& Kulkarni, S. A. (2010). Seismic behavior of reinforced concrete exterior wide beam-column joints. Journal of Structural Engineering, 136(1), 26-36. https://doi.org/10.1061/(ASCE)07339445(2010)136:1(26)

28. Long, X., \& Lee, C. K. (2015). Modelling of two dimensional reinforced concrete beam-column joints subjected to monotonic loading. Advances in Structural Engineering, 18(9), 1461-1474. https://doi.org/10.1260/1369-4332.18.9.1461

29. Lu, X., Urukap, T. H., Li, S., \& Lin, F. (2012). Seismic behavior of interior RC beam-column joints with additional bars under cyclic loading. Earthquake and Structures, 3(1), 37-57. https://doi.org/10.12989/eas.2012.3.1.037

30. Mahini, S. S., \& Ronagh, H. R. (2006). BEAM-COLUMN JOINTS, June, 27-29.

31. Masi, A., Santarsiero, G., Verderame, G. M., Russo, G., Martinelli, E., Pauletta, M., \& Cortesia, A. (2009). Capacity Models of BeamColumn Joints: Provisions of European and Italian Seismic Codes and Possible Improvements. Eurocode 8 Perspectives from the

32. MBIE-NZSEE. (2017). The seismic assessment of existing buildings. Part C5: Concrete buildings. October, 191.

33. Meas, K., Li, B., \& Imran, I. (2012). Seismic performance of lightly reinforced concrete exterior beam-column joints. Advances in Structural Engineering, 15(10), 1765-1780. https://doi.org/10.1260/1369-4332.15.10.1765 
34. Mu, A. (2019). Journal of Chemical Information and Modeling, 53(9), 1689-1699. https://doi.org/10.1017/CBO9781107415324.004

35. Najafgholipour, M. A., Dehghan, S. M., Dooshabi, A., \& Niroomandi, A. (2017). Finite element analysis of reinforced concrete beam-column connections with governing joint shear failure mode. Latin American Journal of Solids and Structures, 14(7), 1200-1225. https://doi.org/10.1590/1679-78253682

36. Narayanan, S. (2013). Introduction to reinforced concrete. Design of RC Structures, November, 1-44.

37. NZS-3101-1. (2006). NZS 3101-1 ( 2006 ): Concrete structures standard - Commentary (Vol. 2).

38. O. C. Zienkiewicz, R. L. Taylor (2000).The finite element method. Volume 1-Butterworth-Heinemann.

39. Pan, Z., Guner, S., \& Vecchio, F. J. (2017). Modeling of interior beam-column joints for nonlinear analysis of reinforced concrete frames. Engineering Structures, 142, 182-191. https://doi.org/10.1016/j.engstruct.2017.03.066

40. Pandey, V. (2018). Finite Element Analysis of Beam Column Joint in RCC Structure. International Journal for Research in Applied Science and Engineering Technology, 6(6), 551-557. https://doi.org/10.22214/ijraset.2018.6087

41. Paulay, T., \& Priestley, M. J. N. (1992). Seismic Design Of Reinforced Concrete Paulay (pp. 362-387).

42. Powell,

$$
\text { G. } \quad \mathrm{H} \text {. }
$$

M.J.N.Priestley,G.M.Calvi,M.J.Kowalsky_Displacement-Based Seismic Design of Structures. In Earthquake Spectra (Vol. 24, Issue 2). https://doi.org/10.1193/1.2932170

43. Priestly, M. J. N. (n.d.). Diplacement Based Seismic Assessment RCBuildings_Priestley.pdf.

44. Raoul, J., Sedlacek, G., Tsionis, G., Raoul, J., Sedlacek, G., \& Tsionis, G. (2012). Eurocode 8: Seismic Design of Buildings Worked examples. https://doi.org/10.2788/91658

45. Ronagh, H. R., \& Dux, R. E. (2005). lexural repair of RC exterior beam-column $j$ oints using sheets.

46. Shaaban, I. G., \& Said, M. (2018). Finite element modeling of exterior beam-column joints strengthened by ferrocement under cyclic loading. Case Studies in Construction Materials, 8(March), 333-346. https://doi.org/10.1016/j.cscm.2018.02.010

47. Sharma, A. (2013). Seismic Behavior and Retrofitting of RC Frame Structures with Emphasis on Beam-Column Joints - Experiments and Numerical Modeling. 413.

48. Sharma, A., Genesio, G., Reddy, G. R., Eligehausen, R., Pampanin, S., \& Vaze, K. K. (2010). 14 th Symposium on Earthquake Engineering EXPERIMENTAL INVESTIGATIONS ON SEISMIC RETROFITTING OF REINFORCED CONCRETE BEAM-. 2.

49. Shiohara, H., \& Shin, Y. W. (2006). Analysis of reinforced concrete knee joints based on quadruple flexural resitance. 8th US Nationa Conference on Earthquake Engineering 2006, 7(1173), 3985-3994.

50. Stanton, J. F., Lehman, D. E., Walker, S. G., \& Yeargin, C. M. (2005). Shear in Reinforced Concrete Beam - Column Joints Without Transverse Reinforcement . 2002, 3-6.

51. Thande, H. M. (2014). Structural Analysis and Design of a Warehouse Building. 73.

52. Uma, S. R. (2015). Seismic Behavior of Beam Column Joints in Reinforced Concrete Moment Resisting Frames. Earthquake, 2(7), 1-36. http://www.iitk.ac.in/nicee/IITKGSDMA/EQ32.pdf\%0Ahttp://www.iitk.ac.in/nicee/IITKGSDMA/EQ31.pdf

53. Uma, S. Rs. B. of B. C. J. in R. C. M. R. F., \& Prasad, A. M. (1996) Seismic Behaviour of Beam Column Joints in Reinforced Concrete Moment Resisting Frames - a Review. 1-36.

54. Uma, S. R., \& Jain, S. K. (2006). Seismic design of beam-column joints in RC moment resisting frames - Review of codes. Structura Engineering and Mechanics, 23(5), 579-597. https://doi.org/10.12989/sem.2006.23.5.579

55. Uma, S. R., \& Jain, S. K. (2006). Seismic design of beam-column joints in RC moment resisting frames - Review of codes. Structural Engineering and Mechanics, 23(5), 579-597. https://doi.org/10.12989/sem.2006.23.5.579

56. Vasani, P. . P. . C., \& Metha B., B. (n.d.). Ductility Requirements for Buildings. 079, 1-10.

57. Vasseva, E., Franchioni, G., \& Krustev, E. (2000). Seismic Design of R / C Frames : an Assesment of Behaviour Factor and a Comparison of Eurocode 8 and Bulgarian Seismic Code. 12th World Conference on Earthquake Engineering, 1-8.

58. Wallace, H. E. (1965). Structural design. Architectural Science Review, 8(1), 5-8. https://doi.org/10.1080/00038628.1965.9696133

\section{AUTHORS PROFILE}

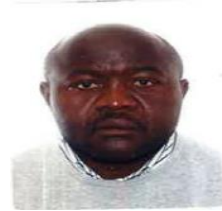

Guillaume Herve POH'SIE, Cameroonian, Assistant Lecturer, Structural Civil Engineer, at the College of Technology (University of Buea Cameroon) Department of Mechanical Engineering.

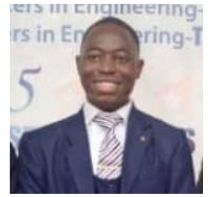

Davy Marcel Bile Bile Abessolo, Cameroonian, Structural Civil Engineer at Nachtigal dam project Cameroon

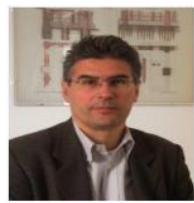

Giuseppe Cardillo, Italian, Structural civil Engineer, assistant professor of Structural Mechanics at the University of Padua.

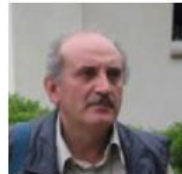

Carmello Majorana, Italian, full Professor of Structural Mechanics and Engineering at the University of Padua

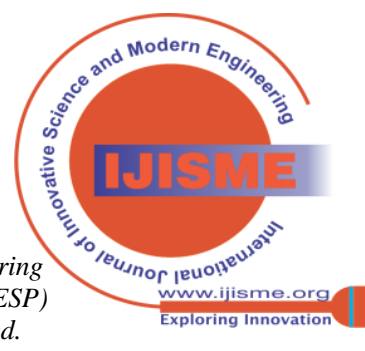

